\title{
Üretimde Kullanılan Endüstri 4.0 Araçlarına Olan İlgi Düzeyinin Yüksek Teknoloji Ürünleri İhracatı Üzerine Etkisi (The Effect of Interest in Industry 4.0 Tools Used in Production on Exports of High Technology Products)
}

\section{Oğuzhan YAVUZ iD a}

a Ankara Hacı Bayram Veli Üniversitesi, İktisadi ve İdari Bilimler Fakültesi, Ankara. Türkiye. oguzhan.yavuz@hbv.edu.tr

\section{MAKALE BİLGİSi \\ Anahtar Kelimeler: \\ Endüstri 4.0 Araçları Yüksek Teknoloji İhracatı \\ Panel Veri Analizi \\ Gönderilme Tarihi 11 Ocak 2021 \\ Revizyon Tarihi 1 Mart 2021}

Kabul Tarihi 25 Mart 2021

\section{Makale Kategorisi:} Araştırma Makalesi

\section{ÖZET}

Amaç - Endüstri 4.0 araçlarına olan ilgi düzeyinin yüksek teknoloji ürünleri ihracatı ve ithalatı üzerine etkisinin belirlenmesi çalışmanın temel amacı olarak belirlenmiştir.

Tasarım/Yöntem/Yaklaşım - Çalı̧̧mada, 2007-2019 yılları arasında 31 ülkenin veri seti kullanılarak yüksek teknoloji ürünleri ithalatı ve ihracatını etkileyen faktörler panel veri analizi ile belirlenmeye çalışılmaktadır. Faktörler; beşeri sermaye, doğrudan yabancı yatırımlar, gayri safi yurtiçi tasarruflar, gayri safi sermaye oluşumu, altyapı, döviz kurları, enflasyon, göç, teknoloji, Ar-Ge, internet kullanımı, patent ve Endüstri 4.0'a olan ilgi düzeyi olarak belirlenmiştir.

Bulgular - Panel veri analizi sonuçlarına göre, ülke ekonomileri açısından ekonomik büyümenin ve sermaye birikiminin artırılmasında önemli olan yurt içi tasarruflar, ülkelerin hem ithalat hem de ihracatını pozitif yönde etkilemektedir. Seçilmiş ülkeler açısından belirli bir dönemde gerçekleştirilen patent sayıları arttıkça yüksek teknoloji ürünleri ithalatı artmakta, ihracatı azalmaktadır. Ayrıca, eğitim seviyesi temel alınarak belirlenen beşeri sermaye değişkeni, orta ve yüksek teknoloji endüstrisi katma değer oranı olarak belirlenen teknoloji değişkeni ve Endüstri 4.0 araçlarına olan ilgi düzeyinin yüksek teknoloji ürünleri ithalatını artırdığı, ihracat üzerinde bir etkisinin olmadığı sonucuna varılmıştır. Tüm değişkenlerin dahil edildiği modelde, ülkelerin bir yıl içerisinde gerçekleştirdiği Ar-Ge harcamalarının ise, yüksek teknoloji ihracatını artırdığı, ithalat üzerinde bir etkisi olmadığı sonucuna varılmıştır.

Tartışma - Dış ticaret açısından ülkelerin yüksek teknoloji ihracatını artırabilmesi için, Endüstri 4.0 araçlarına olan artan ilgi düzeyinin beşeri ve fiziksel sermaye yatırımlarıyla beraber Ar-Ge faaliyetlerinin bir parçası haline dönüştürülmesi gerekmektedir. Elde edilen sonuçlara göre, Ar-Ge harcamaları arttıkça yüksek teknoloji ihracatı da artmaktadır. Böylece, ülke ekonomileri açısından bir tehdit olarak görülebilecek Endüstri 4.0 araçlarına olan ilgi düzeyi bir fırsat haline dönüştürülebilecektir.

\begin{tabular}{l} 
ARTICLE INFO \\
\hline Keywords: \\
Industry 4.0 Tools \\
High Technology Export \\
Panel Data Analysis
\end{tabular}

Received 11 January 2021

Revised 1 March 2021

Accepted 25 March 2021

Article Classification: Research Article

\section{ABSTRACT}

Purpose - Determining the effect of the level of interest in Industry 4.0 on the export and import of high technology products has been determined as the main purpose of the study.

Design / Method / Approach - In the study, the factors, such as human capital, foreign direct investments, gross domestic savings, gross capital formation, infrastructure, exchange rates, inflation, immigration, technology, R\&D, internet usage, patent, and the level of interest in Industry 4.0, affecting the import and export of high technology products are determined by panel data analysis using the data set of 31 countries between 2007-2019.

Findings - According to the results of the panel data analysis, domestic savings, which are important in increasing economic growth and capital accumulation, positively affect both import and export of countries. In terms of selected countries, as the number of patents in a certain period increases, the import of high technology products increases, and its exports decrease. In addition, it was concluded that the human capital variable determined based on education level, the technology variable determined as the medium and high technology industry value added rate, and the level of interest in Industry 4.0 tools increased the imports of high technology products and had no effect on exports. In the model where all variables are included, it is concluded that the R\&D expenditures made by countries within a year increase high technology exports and have no effect on imports.

Discussion - For countries to increase their high technology exports in terms of foreign trade, the increasing interest in Industry 4.0 tools should be transformed into a part of R\&D activities together with human and physical capital investments. According to the findings, as R\&D expenditures increase, high technology exports also increase. Thus, the level of interest in Industry 4.0 tools, which can be a threat to the national economies, can be transformed into an opportunity.

\footnotetext{
${ }^{1} \mathrm{Bu}$ makale 2020 yılında gerçekleştirilen The International Symposium on Business and Economics (ISBE) sempozyumunda sunulan çalışmadan türetilmiştir. 


\section{Giriş}

Geleneksel faktör donatımı teorisine göre, ülkeler görece kıt kaynakları kullanılarak üretilen malları ithal ederken, kendi ülkesinin görece bol kaynakları kullanılarak üretilen malları ihraç etmelidir (Liu ve Shu, 2003:48). Gelişmekte olan ülkeler genellikle yüksek teknoloji içeren ürünleri gelişmiş ülkelerden ithal etmektedir (Göçer, 2013: 216; Huang vd., 2008: 310). Gelişmiş ülkeler ise genellikle yüksek teknoloji ürünleri üreten ve ihraç eden konumda bulunmaktadır. Ülkeler, ihracata dayalı ekonomik büyüme modelini tercih ederek, kaynakları daha etkin kullanabilmekte ve katma değeri yüksek ürünler üreterek ihraç edebilmektedirler. Özellikle gelişmekte olan ülkelerde katma değeri yüksek olan yüksek teknoloji ürünlerinin üretilmesi ve ihraç edilebilmesi sürdürülebilir bir büyüme sağlayabilecektir (Özer ve Çiftçi, 2009: 47). Dolayısıyla, ülkelerin ekonomik büyümesinde yüksek teknoloji ürünleri ihracatının önemli bir yeri olduğu söylenebilir. Ar-Ge harcamaları, yenilikçilik ve bilgi teknolojileri gibi teknolojinin üretilmesi ve dağıtımı ile ilgili teknolojik faktörlerin ekonomik büyüme üzerinde önemli bir etkisinin olduğu görülmektedir (Romer, 1986: 1034; Grossman ve Helpman, 1990: 91; Cheng ve Dinopoulos, 1992: 409,410; Pohjola, 2000: 14; Jones, 1995: 521).

Ar-Ge, yenilikçilik ve bilgi teknolojileri gibi teknolojik faktörlerin aynı zamanda yüksek teknoloji ürünlerin ihracatını da olumlu yönde etkilediği literatürden anlaşılmaktadır (Özer ve Çiftçi, 2009: 47; Yıldırım ve Kesikoğlu, 2012: 175). Yıldırım ve Keskinoğlu (2012: 168,169) çalışmalarında; 1985 - 2012 yılları arasında gerçekleştirilen otuz altı çalışmayı incelemişler ve sadece altı çalışmada Ar-Ge harcamaları ile ihracat arasıda anlamlı bir ilişki olmadığını ortaya koydukları görülmektedir (Nassimbeni, 2001: 260; Liu ve Shu, 2003: 55; Huang vd., 2008: 311; Harris ve Li, 2009: 93; D'Angelo, 2012: 415; Wignaraja, 2012: 232). Çalışmaların büyük çoğunluğunda ülkelerin ihracat rakamları üzerinde Ar-Ge harcamaları ve diğer teknolojilerin etkisi olduğu görülmüştür.

Gelişmekte olan ülkelerde işletme düzeyinde inovasyon ve öğrenme, genellikle teknolojik yeteneklerin, yani ithal edilen teknolojileri verimli bir şekilde kullanmak için gereken bilgi ve becerilerin edinilmesi olarak tanımlanır (Wignaraja, 2012: 224). Göçer (2013)'e göre benzer durumlarda, "ülkelerin ithalatı, ihracatından daha çok artabilmekte ve bu süreç ülkenin aleyhine işleyebilmektedir". İthal edilen teknolojileri verimli bir şekilde kullanmak için işletmelerin teknoloji arama, eğitim, mühendislik ve (hatta) Ar-Ge'ye bilinçli yatırımlar yapmaları gerekmektedir. İthal teknolojileri verimli kullanmak ise, ihracat oranların artıracaktır (Wignaraja, 2012: 226).

Schumpeter (1970)'ın yaratıcı yıkım teorisine göre, ürün çeşitlendirmede yeni teknolojilerin önemi büyüktür ve "temel itici güc, yeni tüketim malları, yeni üretim veya teslimat yöntemleri ve yeni pazar arayışıdır" (Özer ve Çiftçi, 2009:40). Yeni ürün üretim ve dağıtım yöntemleri ise teknolojik gelişmelerden bağımsız düşünülemez. Son yıllarda, yüksek teknolojili ürünler üreten veya kullanan birçok işletme dördüncü sanayi devrimi (Endüstri 4.0) olarak tanımlanan yeni üretim yöntemlerine ve sistemlerine ilgi göstermeye başlamıştır. Endüstri 4.0'a yönelik gelişme, şu anda imalat endüstrisi üzerinde önemli bir etkiye sahiptir (Bakınız. Stock ve Seliger, 2016).

Çalışmada, üretimde kullanılan Endüstri 4.0 araçlarına ilgi düzeyinin ülkelerin yüksek teknoloji ürünlerin ihracatına etkisi incelenecektir. Literatürde Ar-Ge, yenilikçilik ve patent sayıları ile yüksek teknoloji ürünlerin ihracatı arasında pozitif ve istatistiksel olarak anlamlı bir ilişkinin olduğu gösterilmiştir. Ancak, Endüstri 4.0 teknolojileri ile olan ilişki düzeyini belirten çalışmalara pek rastlanılmamaktadır. Ayrıca, ithalat ve ihracat arasındaki dış ticaret dengesi açısından yüksek teknoloji ürünlerin ihracatında dolaylı olarak ithalatında etkisinin olduğu görülmektedir. Çalışmada, ilave olarak, Endüstri 4.0 teknolojilerine ilgi düzeyinin yüksek teknoloji ürünleri ithalatı üzerindeki etkisi de incelenecektir. Böylece dış ticaret rakamları açısından Endüstri 4.0 teknolojilerine ilgi düzeyi arttıkça, yüksek teknoloji ürünleri ithalat ve ihracat rakamları üzerindeki etkisi anlaşılmaya çalışılacaktır.

\section{Literatür Taraması}

İhracatın ekonomik büyüme üzerinde olumlu etkisinin olduğu bilinmektedir. İthalatın ise, özellikle dış ticaret dengesi açısından olumsuz bir etkisinin olduğu ifade edilmektedir. Ancak, özellikle yüksek teknoloji ürünleri ithalatının teknoloji transferine neden olacağı (Şeker, 2018: 601) ve yurt içinde üretimi ve verimliliği artırdığı sonucuna varılmaktadır (Kurt ve Zengin, 2016: 68). Yüksek teknoloji ürünleri ithalat ve ihracatı, günümüzde 


\section{O. Yavuz 13/1 (2021) 825-843}

dördüncü sanayi devrimi olarak bilinen yeni bir takım teknolojik gelişmelerden etkilenmektedir. Üretimde kullanılan Endüstri 4.0 araçları, ülkelerin hem yüksek teknoloji ürünlerine olan ihtiyacını artırmakta, hem de ihracat üzerinde dolaylı bir etkiye sahip olduğu düşünülmektedir.

Endüstri 4.0 kavramı, akıllı fabrikalarda, sanal ve fiziksel dünyaların siber-fiziksel sistemler aracılığıyla birleştirilmesi ve sonuçta ortaya çıkan teknik ve iş süreçlerinin füzyonu olarak tanımlanmaktadır. Endüstri 4.0, bir ekonomideki tüm üretim birimlerinin tutarlı bir şekilde dijitalleştirilmesi ve birbirine bağlanması fikrine dayanmaktadır. Endüstri 4.0 olarak bilinen yeni djital endüstriyel teknolojinin yükselişi, dokuz temel teknoloji ilerlemesiyle desteklenen bir dönüşüm sürecidir (Şekil 1). Dönüşüm sürecinde sensörler, makineler, iş parçaları ve bilgi teknolojisi sistemleri değer zinciri boyunca birbirine bağlanmaktadır (Rüßmann vd., 2015: $1)$.

Endüstri 4.0 teknolojileri, üretim sistemlerinin yatay ve dikey entegrasyonu ilkelerine göre çalışır ve değer zincirindeki gerçek zamanlı veri alışverişini ifade etmektedir. Bulut bilişim, nesnelerin interneti, büyük veri analitiği, eklemeli üretim, robotik sistemler, artırılmış gerçeklik, similasyon, yatay ve dikey sistem entegrasyonu ve siber-güvenlik Endüstri 4.0'in temel bilgi teknolojisi bileşenleridir (Wan vd., 2016: 8977; Kamble vd., 2018: 417-418; Bahrin vd., 2016: 138).

Bulut bilişim, internette veri veya veri tabanının depolanması için kullanılan üçüncü taraf bir hizmet sağlayıcısıdır. Bulut teknolojileri, birbirine uzak mesafelerde bulunan işletmelerin daha fazla veri paylaşımı yapabilmelerini, daha çevik ve esnek sistemlere sahip olmalarını ve çevrim içi sistemler kullanılarak maliyetleri düşürebilmelerini sağlamaktadır (Kamble vd., 2018: 417).

Nesnelerin interneti, siber-fiziksel sistem ve akıllı üretim konularını kapsayan Endüstri 4.0 kavramı içerisinde kitlesel özelleştirilmiş üretim talebinin artmasının bir sonucudur (Li vd., 2017:1855). Nesnelerin interneti, "fiziksel ve sanal nesnelerin kimliklere, fiziksel özelliklere ve sanal kişiliklere sahip olduğu ve akıllı arayüzler kullandığı standart ve birlikte çalışabilir iletişim protokollerine dayanan, kendi kendini yapılandırma yeteneklerine sahip ve bilgi ağına sorunsuz bir şekilde entegre edilebilen dinamik bir küresel ağ altyapısıdır" (Kranenburg, 2008: 414). Nesnelerin interneti, herhangi bir insan müdahalesi olmaksızın makineler arasındaki etkileşimi sağlamaktadır (Xu vd., 2014: 2234). Ayrıca, Nesnelerin interneti "teknolojisinin temel prensibi veriyi elde etme, veriyi paylaşma ve veriyi analiz etme süreçlerine dayanmaktadır" (Özer, 2020: 89).

Endüstri 4.0 veri toplama, depolama, analiz ve paylaşım teknolojileri gerektirmektedir. Büyük veri, daha önceki yöntemlerle depolanması, işlenmesi ve analiz edilmesi zor olan büyük ve karmaşık veri kümelerinin toplanması için bir şemsiye terim olarak kullanılmaktadır. Büyük veri analitiği, bilgisayar bilimi, veri bilimi, istatistik ve matematiksel modeller kullanan disiplinler arası bir alan olup, gerçek zamanlı veri toplama, analitik araçların kullanımı ve gelişmiş karar verme araçları için bilgisayar algoritmaları kullanma anlamına gelmektedir (Jeble vd., 2018; 1,6). Verilerin paylaşılması ise güvenlik sorunları meydana getirmektedir. Günümüzde, siber güvenlik sadece güvenilir iletişim anlamına gelmemekte, ayrıca makinelerin ve kullanıcıların gelişmiş kimlik ve erişim yönetimi, artan bağlanabilirlik ve standart iletişim protokollerinin kullanımıyla ilgili önemli ölçüde artan siber güvenlik tehditleri sorununu ifade etmektedir (Bahrin vd., 2016: 139).

Eklemeli üretim, bilgisayar destekli tasarım yazılımı kullanılarak üç boyutlu bir dijital model oluşturulması ve ardından 3 boyutlu yazıcı kullanılarak nihai ürün oluşturulması anlamına gelmektedir. Dijital bir modele dayanarak, binaların veya nesnelerin 3 boyutlu baskısı, tüm nesne oluşana kadar malzeme katmanları üzerine katman katman eklenerek elde edilmektedir (Oesterreich ve Teuteberg, 2016: 129).

Akıllı gözlükler ve akıllı telefon teknolojileri kullanan artırılmış gerçeklik tabanlı uygulamaların endüstriyel robot kullanan üretim sistemlerinin verimliliğini artırdığı görülmüştür Artırılmış gerçeklik uygulamaları, standartlaştırılmış grafik kullanıcı arayüzleri, insan-makine arayüzleri veya artırılmış ve sanal gerçeklik ortamının bir parçası olarak grafik bilgileri şeklinde veri sağlamaktadır (Malý vd., 2016: 176).

Robotik teknolojiler, esas olarak akıllı fabrikalarda ürünlerin üretim yoluyla kendi yollarını bulabildikleri ve aksaklıklar durumunda alternatifler oluşturabilecekleri siber fiziksel sistemlerdir. Endüstri 4.0'da robotlar ve insanlar, akıllı sensörlerle insan-makine arayüzlerini kullanarak beraber çalışabilmektedirler. Robotlar üretim, lojistik ve ofis yönetimi (belgeleri dağıtmak için) gibi birçok alanda kullanılmakta ve uzaktan kontrol edilebilmektedir (Bahrin vd., 2016: 139). 


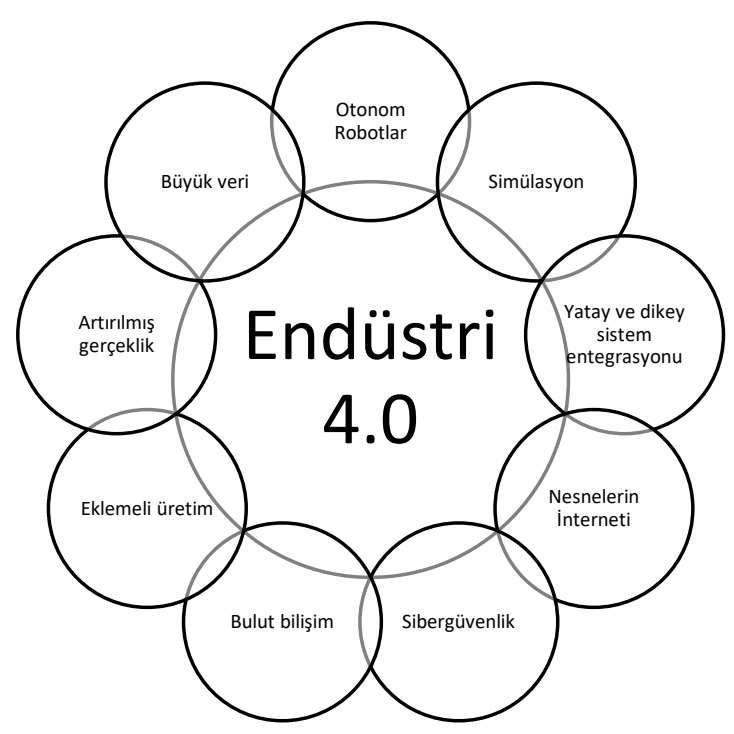

Şekil 1. Endüstri 4.0 Bileşenleri (Rüßmann vd., 2015: 1).

Literatürde teknolojik gelişmelerin yüksek teknoloji ihracatını etkilediğine dair birçok çalışmaya rastlanmaktadır. Çalışmaların bir kısmı yüksek teknoloji ürün ihracatını sadece ekonomik değişkenler açısından ele alırken, son yıllarda Ar-Ge harcamaları, patentler, bilgi teknolojleri gibi teknolojik değişkenlerin daha sıklıkla kullanıldığı görülmektedir. Tebaldi (2011), 1980 ile 2008 yılları arasındaki veri setini kullanarak panel veri analizi ile yüksek teknoloji ürünleri ihracatını etkileyen etmenleri belirlemeye çalışmıştır. İnsan kaynağı (eğitim durumu), doğrudan yabancı sermaye yatırımı, ihracat ve ithalat toplamının yurt içi hasılaya oranı, gayri safi yurt içi tasarruflar (yurt içi hasılaya oranı), göçmenler (1000 kişi başına düşen \%), döviz kuru indeksi, gayri safi sermaye birikimi ve enflasyon değişkenlerini kullanmıştır. Yedi ayrı model üzerinden gerçekleştirdiği tahmin değerlerine göre, insan kaynağı, doğrudan yabancı sermaye yatırımları ve ihracat ve ithalat toplamı ile yüksek teknoloji ürünleri ihracatı arasında pozitif yönde ve istatistiksel olarak anlamlı bir ilişki olduğu sonucuna ulaşmıştır.

Yüksek teknoloji ürünleri ithalatı ve ihracatı üzerine gerçekleştirilen çalışmaların bir kısmı teknolojik değişkenler üzerine odaklanmaktadır. Zhang (2007), genel olarak, 1985 - 1998 yılları arası verileri kullanarak, orta ve yüksek teknoloji ihracatını etkileyen unsurları regresyon yöntemini kullanarak belirlemeye çalışmıştır. Yetenek, doğrudan yabancı sermeye yatırımı, alt yapı (enerji ve iletişim için gerekli yol vb.) ve teknolojik yetenek temel belirleyici unsurlar olarak seçilmiştir. İhracat üzerinde altyapı ve endüstriyel teknolojik yeteneğin temel belirleyici faktörler olduğu gösterilmiştir. Endüstriyel teknoloji kapasitesi, orta ve yüksek teknoloji ürünler için kişi başına üretim değeri veya orta ve yüksek teknolojili ürünler üretme yeteneği ve kapasitesi olarak tanımlanmıştır. Altyapı değişkeni ise, belirtilen dönemde 1000 kişi başına düşen telefon hatlarının sayısı ile ölçülmüştür.

Srholec (2007), regresyon yöntemiyle gelişmekte olan ülkelerin yüksek teknoloji ihracatını etkileyen özellikleri belirlemekle birlikte, elektronik ürünlerin ihracatı üzerine odaklanmıştır. Ekonominin büyüklügü ve teknolojik yetenek değişkenleri ile belirlenmiştir. Farklı olarak, çalışmada teknolojik yetenek, yüksek öğretime kayıt yapanların sayısı, verilen patent sayıları ve bilgisayara erişim düzeyi ile ölçülmüştür. Dolayısıyla, belirtilen faktörlerin yüksek teknoloji ürünleri ihracatı üzerine etkisi belirlenmeye çalışılmıştır. Elektronik bileşenleri ithal etme eğilimi çok daha fazlasını açıklasa da, teknolojik yeteneklerin elektronik ihracatında uzmanlaşma için önemli olduğu çalışmada doğrulanmıştır.

Eaton ve Kortum (2002), insan kaynağı, teknoloji, işgücü verimliliği ve ürünlerin kalitesi faktörlerininin dış ticarete etkisini incelemişlerdir. Ayrıca, yenilikçilik, fiyat artışı, karlılık, teşvikler ve ekonomik büyüme değişkenlerinin ticaret ve pazar verileri üzerindeki etkisini araştırmışlardır. Özellikle yenilikçilik üzerine odaklanan çalışmanın sonuçlarında, işbirliğine dayalı teknolojilerin sadece yenilikçi ürünlerin ihracatına sebep olmadığı, aynı zamanda fikirlerin de hareketi anlamına geldiğini ifade edilmektedir.

Sandu ve Ciocanel (2014) çalışmalarında, Ar-Ge ve yeniliğin etkisini araştırmışlardır. 2007 ile 2012 yılları arasındaki verileri kullanarak gerçekleştirdikleri çalışmalarında, panel veri analizi yöntemini kullanarak, yirmi altı ülke verilerini karşılaştırmışlardır. Bağımlı değişkenin yüksek teknoloji ihracatı olduğu çalışmada, 


\section{O. Yavuz 13/1 (2021) 825-843}

bağımsız değişkenler olarak; toplam istihdam içerisinde bilgi yoğun faaliyetlerde çalışanların oranı; toplam ihracat (gayri safi hasılaya oranı); kamu ve özel sektör Ar-Ge yatırımları (gayri safi hasılaya oranı) ayrı ayrı ele alınmıştır. Sonuç olarak, kamu sektöründe Ar-Ge yatırımlarında meydana gelen yüzde bir birimlik bir artışın toplam ihracat içinde yüksek teknoloji ürünleri ihracatının payını yüzde sekiz artıracağı; işletmelerin Ar-Ge harcamalarındaki artışın ise yüzde dokuz artıracağı görülmüştür.

Özer ve Çiftçi (2009), 1993-2005 yılları arasındaki verileri kullanarak OECD ülkelerinde, Ar-Ge harcamaları ile genel ihracat, bilgi ve iletişim teknolojileri ihracatı ve ileri teknoloji ihracatı arasındaki ilişkiyi araştırmışlardır. Çalışmada, OECD ülkeleri için Ar-Ge ile ihracat arasında pozitif ve yüksek oranlı bir ilişki olduğu ortaya çıkmıştır. Göçer (2013), yüksek teknoloji ürün ihracatında Ar-Ge harcamalarının ve diş ticaret dengesi üzerinde yüksek teknoloji ürün ihracatının etkisini panel veri anallizi kullanarak araştırmıştır. Sonuç olarak, Ar-Ge harcamalarındaki yüzde birlik artışın yüksek teknoloji ürün ihracatını yüzde altı buçuk oranında arttırdığı tespit edilmiştir. Braunerhjelm ve Thulin (2008), 1981-1999 yılları arası 19 OECD ülkesinin verilerini kullanarak panel veri analizi yöntemini kullanmış, kamunun eğitim harcamaları (yurt içi hasılaya oranı), doğrudan yabancı sermaye yatırımları (yurt içi hasılaya oranı), toplam kamu ödemeleri (yurt içi hasılaya oranı) ve Ar-Ge harcamaları (yurt içi hasılaya oranı) değişkenlerinin yüksek teknoloji ihracatı üzerine etkisini araştırmışlardır. Ar-Ge harcamalarında yüzde bir puanlık bir artışın, yüksek teknoloji ürünleri ihracatında yüzde üç puanlık bir artışa sebep olduğu sonucuna ulaşmışlardır.

Kızılkaya vd. (2017), yüksek teknoloji ürün ihracatını doğrudan yabancı sermaye yatırımları ve dışa açıklığın pozitif yönde etkilediğini ortaya koymuştur. Ayrıca, çalışmada ekonomik büyüme ve patentlerin yüksek teknoloji ürünleri ihracatını pozitif yönde etkilediği belirlenmiştir. Diğer çalışmaların aksine, Ar-Ge değişkeni ile yüksek teknoloji ürünleri ihracatı arasında anlamlı bir ilişki bulunmamıştır.

Montobbio ve Rampa (2005), 1985-1998 yılları arasında dokuz gelişmekte olan ülkenin ihracat performanslarını incelemiş, teknolojinin ve yapısal değişimlerin ihracat üzerindeki etkisi belirlenmeye çalışılmıştır. Yapısal ayrıştırma analizi kullanılarak yapılan incelemelerde, yüksek teknoloji ürünleri üreten sektörlerde, ihracat performansı; teknolojik faaliyetlerden, teknik yeteneklerden, doğrudan yabancı yatırımlardan, üretkenlikten, başlangıç seviyesindeki teknik becerilerden ve orta teknolojideki doğrudan yabancı yatırımların büyüme oranlarından etkilenmektedir.

Literatürde yüksek teknolojili ürünlerin ithalat ve ihracatını etkileyen faktörler ile ilgili çeşitli çalışmalar bulunmaktadır. İnsan sermayesi, doğrudan yabancı yatırımlar, kurumlar (gayri safi yurtiçi tasarruf, gayri safi sermaye oluşumu), yatırım, altyapı, döviz kurları, göç, makroekonomik dalgalanma (enflasyon), teknolojik yetenek, Ar-Ge yoğunluğu, patentler, bilgisayara erişim ve ürünlerin kalitesi gibi yüksek teknoloji ithalatını veya ihracatını etkileyen çeşitli değişkenler kullanılmıştır (Barro ve Lee, 2010; Tebaldi, 2011; Zhang, 2007; Srholec, 2007; Braunerhjelm ve Thulin, 2008; Eaton ve Kortum, 2002; Montobbio ve Rampa, 2005; Özer ve Çiftci, 2009; Sandu ve Ciocanel, 2014).

Yüksek teknoloji ihracatı ve ithalatı üzerine gerçekleştirilen çalışmalarda sonuçların elde edilmesinde panel veri analizi (Kılıç vd., 2014; Özçelik vd., 2018; Kızılkaya vd., 2017; Göçer, 2013; Özer ve Çiftçi, 2009; Özkan ve Yılmaz, 2017; Anaruo ve Di Pietro, 2006; Kılavuz vd., 2012; Türedi, 2013; Gökmen ve Turen, 2013; Yıldız, 2017; Kabaklarli vd., 2017; Gaberli 2018; Şahbaz vd., 2014; Braunerhjelm ve Thulin, 2006; Jarreau ve Poncet , 2012; Sandu ve Ciocanel, 2014; Yaman ve Sungur, 2020), genelleştirilmiş momentler methodu (GMM) (Erdil vd., 2009; Falk, 2009), regresyon yöntemi (Akyol ve Demez, 2020), çekim modeli (İsmail, 2013), çoklu doğrusal regresyon (Yavuz ve Uysal, 2020), Granger nedensellik testi (Yapraklı ve Sağlam, 2010; Gökmen ve Turen, 2013; Çetin, 2016; Telatar vd., 2016; Şeker, 2019; Şahin, 2019; Toplallı, 2015; Dereli, 2019), VAR methodu (Güneş ve Akın, 2019; Erkişi ve Boğa, 2019), karşılaştırmalı analiz (Singh, 2006) ve tam değiştirilmiş en küçük kareler yöntemi (Bolkan ve Kaplan, 2020) gibi çeşitlli yöntemlerin kullanıldığı görülmektedir. Diğer taraftan Endüstri 4.0 teknolojileri ile yüksek teknoloji ithalat ve ihracatı arasındaki ilişkiyi gösteren çalışma sayısı azdır. Benzer çalışmalarda Granger nedensellik analizi (Öztürk ve Alaşahan, 2019; Erdal, 2018) ve GMM (Çoban ve Balıkçığlu, 2020) gibi yöntemlerin kullanıldığı literatürden anlaşılmaktadır. Liu vd. (2020), çalışmalarında panel veri analizi ile yapay zekanın teknolojik yenilikçilik üzerindeki etkisini ortaya koymuş, yapay zekanın Ar-Ge harcamalarını artırarak teknolok yenilikçiliği teşvik ettiğini belirtmişlerdir. Endüstri 4.0 teknolojileri ve yüsek teknoloji arasındaki ilişkiye yönelik panel veri analizinin uygulandığı çalışmalar sınırlıdır. 


\section{Araştırma Modeli ve Veri Seti}

\subsection{Veri Seti}

Endüstri 4.0; yapay zeka, bulut bilişim, robotik teknolojiler, artırılmış gerçeklik, eklemeli üretim, nesnelerin interneti (Üstündağ ve Çevikcan, 2017), büyük veri (Lee, Kao ve Yang, 2014), simülasyon (Rodic, 2017), sistem entegrasyonu (Rüßmann, 2015) ve siber güvenlik (Thames ve Schaefer, 2017) gibi çeşitli dijital ve fiziksel teknolojilerin birleşiminden oluşmaktadır. İşletmeler, Endüstri 4.0 bileşenlerini kullanmaya başladıkça ihtiyaç duydukları yüksek teknoloji ürünlerine olan ihtiyaç artmakta ve yüksek teknoloji ürünlerini ithal etmektedirler. Diğer taraftan, bazı işletmeler de artan ihtiyaca cevap verebilmek amacıyla yüksek teknoloji ürünlerini diğer ülke pazarlarına ihraç etmektedirler. Çalışmada, Endüstri 4.0'ın ilgi düzeyine (popülaritesine) bağlı olarak ülkelerdeki yüksek teknoloji ürünleri ithalatının ve ihracatının artıp artmadığı tespit edilmeye çalışılmıştır.

Çalışmada, üretimde kullanılan Endüstri 4.0 (END4) bileşenlerinin popülaritesinin ülkelerin yüksek teknolojili ürünlerin ithalatını (YTİ) ve ihracatını (YTIH) etkilediği düşünülmektedir. Bu amaçla, Endüstri 4.0'n popülaritesi ile ülkelere ithal edilen yüksek teknolojili ürünler arasındaki ilişki panel veri analizi ile incelenmiştir. Aralarındaki ilişki; Türkiye, Rusya, Polonya, Macaristan, Bulgaristan, Hırvatistan, Romanya, Fransa, Almanya, İtalya, Birleşik Krallık, Avusturya, Belçika, Çek Cumhuriyeti, Danimarka, Estonya, Finlandiya, Yunanistan, İrlanda, Letonya, Litvanya, Lüksemburg, Hollanda, Norveç, Portekiz, Slovakya, İspanya, İsveç, ABD, Kanada, Japonya gibi seçilmiş ülkelerde üç farklı modelle ölçülmüştür.

Modeli tahmin etmek için kullanılan veriler üç kaynaktan gelmektedir. Endüstri 4.0 verilerinin popülerliği Google Trends verilerinden elde edilmiştir. Diğer tüm değişkenler; Dünya Bankası, Dünya Kalkınma Göstergelerinden (World Development Indicators) ve OECD veri setinden alınmıştır. Veri sınırlaması nedeniyle, ampirik analiz 2007'den 2019'a kadar olan dönemi dikkate almaktadır.

Analizde; beşeri sermaye (BS), doğrudan yabancı yatırımlar (DYSY), gayri safi yurtiçi tasarruflar (YİT), gayri safi sermaye oluşumu (SO), altyapı (AY), döviz kurları (DK), enflasyon (ENF), göç (GÖÇ), teknoloji (TEK), ArGe (AG), internet kullanımı (INT), patent (PAT) ve Endüstri 4.0'a olan ilgi düzeyi (END4) değişkenlerinin yüksek teknoloji ürünleri ithalatı (YTI) ve ihracatı (YTİH) üzerinde etkili olup olmadığı araştırılmıştır.

Endüstri 4.0'ın popülaritesini belirlemek için Google Trends sonuçları kullanılmıştır. Google Trends, kullanıcıların Google hizmetleri üzerinden arama yaptığı konuları gerçek zamanlı olarak görmenize olanak tanıyan bir hizmettir. Çeşitli bölge ve dillerde, Google Arama'da en çok yapılan arama sorgularının arama hacmini analiz etmek için grafikler kullanan bir web sitesidir. Arama sorgularının popülerlik puanı, tüm aramalarla orantılı bir konuya göre 0 ila 100 arasında ölçeklenir. Bu nedenle, Google Trends puanları, aranan kelimelerin veya kelime öbeklerinin popülerlik düzeyini göstermektedir.

Çalışmada, Endüstri 4.0 bileşenlerinin her birinin Google Trends puanları, her ülke için ayrı ayrı elde edilmiştir. Böylece her bir bileşenin Google aramadaki oranları, yani popülaritesi belirlenmiştir. 2007-2019 yılları arasında her ülke için yapay zeka, bulut bilişim, robotik teknolojiler, artırılmış gerçeklik, eklemeli üretim, nesnelerin interneti, büyük veri, simülasyon, sistem entegrasyonu ve siber güvenlik gibi Endüstri 4.0 bileşenlerinin arama puanları belirlenmiştir. Daha sonra, tüm ülkelerin ortalamaları alınarak her bileşenin yıllık bazda ortalama puanları elde edilmiştir. Tüm bileşenlerin Google Trends puanlarının ortalaması alınarak, yıllık bazda tek bir ortalama Endüstri 4.0 puanı elde edilmiştir. Google Trends yalnızca 2007'den sonra veri yayınladığı için, panel veri analizi 2007 ile 2019 arasındaki yıllık verilerden oluşmaktadır. 2019 yılı sonrası veriler ise, yüksek teknoloji ürünlerine olan dış ticaret engelleri nedeniyle çalışmada ele alınmamıştır.

Çalışmanın en önemli sınırlılı̆̆ı, Aralık 2019'dan bu yana COVID-19 salgını nedeniyle ülke ekonomilerinde yaşanan durgunluktur (Aktura, 2020: 45). Çalışmada pandemi dönemi etkilerinin halen devam etmesi nedeniyle veri setini manipüle edebileceği düşünüldügünden 2020 yılı verileri analize dahil edilmemiştir. Elde edilen sonuçlar seçilmiş ülkeler açısından 2007 ile 2019 arasındaki yıllık veriler dikkate alınarak yorumlanmıştır. 
O. Yavuz 13/1 (2021) 825-843

(1)

$$
I N D 4_{\ddot{U} l k e(y \imath l l l k)}=\frac{\sum_{i=1}^{n} x}{n}
$$

$$
x_{1}, x_{2}, x_{3}, \ldots, x_{n} \geq 0 \text { ve } n=10
$$

Burada,

$\mathrm{x}_{1}=$ Bir ülke için bir yılda "yapay zeka" aramaları için Google Trends puanı,

$\mathrm{x}_{2}=$ Bir ülke için bir yılda "bulut bilişim" aramaları için Google Trends puanı,

$\mathrm{x}_{3}=$ Bir ülke için bir yılda "robotik teknolojiler" aramaları için Google Trends puanı,

$\mathrm{x}_{4}=$ Bir ülke için bir yılda "artırılmış gerçeklik" aramaları için Google Trends puanı,

$\mathrm{x}_{5}=$ Bir ülke için bir yılda "eklemeli üretim" aramaları için Google Trends puanı,

$\mathrm{x}_{6}=$ Bir ülke için bir yılda "nesnelerin internet" aramaları için Google Trends puanı,

$\mathrm{X} 7=$ Bir ülke için bir yılda "büyük veri" aramaları için Google Trends puanı,

$\mathrm{x}_{8}=$ Bir ülke için bir yılda "simülasyon" aramaları için Google Trends puanı,

x9= Bir ülke için bir yıl içindeki "sistem entegrasyonu" aramaları için Google Trends puanı,

$\mathrm{x}_{10}=$ Bir ülke için bir yılda "siber güvenlik" aramaları için Google Trends puanıdır.

Değişkenlerle ilgili tanımlayıcı istatistikler aşağıdaki Tablo 1'de verilmiştir.

Tablo 1. Tanımlayıcı İstatistikler

\begin{tabular}{lcccccccc} 
& YTI & BS & DYSY & YíT & SO & ENF & DK & GÖÇ \\
\hline Ortalama & 27.81 & 78.61 & 5.70 & 25.01 & 22.46 & 3.57 & 12.95 & 0.08 \\
\hline Medyan & 26.31 & 78.30 & 2.40 & 23.73 & 22.33 & 3.67 & 0.90 & 0.06 \\
\hline Maksimum & 72.19 & 89.67 & 86.61 & 55.85 & 41.54 & 4.23 & 281.52 & 0.81 \\
\hline Minimum & 8.14 & 66.64 & -58.32 & 8.33 & 10.22 & 2.57 & 0.48 & 0.00 \\
\hline Standard Sapma & 10.50 & 3.97 & 12.51 & 8.35 & 4.26 & 0.43 & 43.21 & 0.11 \\
\hline Çarpıklık & 0.83 & 0.04 & 2.84 & 1.34 & 0.55 & -0.51 & 4.61 & 4.10 \\
\hline Basıklık & 4.18 & 2.47 & 18.62 & 6.03 & 4.84 & 2.13 & 24.25 & 24.09 \\
\hline Toplam & 8983.32 & 25389.44 & 1841.01 & 8077.30 & 7255.77 & 1151.71 & 4181.46 & 27.45 \\
\hline & $\mathbf{A Y}$ & TEK & AG & INT & PAT & END4 & YTI + YTİH \\
\hline Ortalama & 2.23 & 40.88 & 1.65 & 73.28 & 17824.21 & 25.48 & 104.47 \\
\hline Medyan & 1.80 & 42.70 & 1.45 & 75.23 & 1390.00 & 21.59 & 84.58 \\
\hline Maksimum & 15.53 & 64.51 & 3.75 & 98.14 & 295327.00 & 68.33 & 408.36 \\
\hline Minimum & -4.48 & 7.11 & 0.38 & 28.30 & 15.00 & 8.68 & 24.64 \\
\hline Standard Sapma & 2.53 & 12.34 & 0.87 & 15.65 & 57622.11 & 12.66 & 63.99 \\
\hline Çarpıklık & 1.87 & -0.33 & 0.59 & -0.58 & 4.02 & 1.04 & 2.18 \\
\hline Basıklık & 8.75 & 2.43 & 2.24 & 2.60 & 17.79 & 3.37 & 9.42
\end{tabular}

\subsection{Araștırma Modeli}

Çalışmada, 2007-2019 yılları arasındaki yıllık verilerden elde edilen veri seti ile yüksek teknoloji ürünleri ithalat ve ihracatını etkileyen faktörler panel veri analizi sonucunda elde edilmiştir. Panel veri analizi ile aşağıdaki model tahmin edilmektedir:

$$
H T I_{i, t}=\beta X_{i, t-1}+v_{i}+\varepsilon_{i, t}
$$

(3)

$$
\operatorname{HTEX}_{i, t}=\beta X_{i, t-1}+v_{i}+\varepsilon_{i, t}
$$




\section{O. Yavuz 13/1 (2021) 825-843}

Panel veri analizinde; i, ülkeleri; t, zamanı; YTİ, yüksek teknoloji ithalatını ve YTİH, yüksek teknoloji ihracatını ölçtüğü yerde, X, beşeri sermaye (BS), doğrudan yabancı yatırımlar (DYSY), gayri safi yurtiçi tasarruflar (YİT), gayri safi sermaye oluşumu (SO), altyapı (AY), döviz kurları (DK), enflasyon (ENF), göç (GÖÇ), teknoloji (TEK), Ar-Ge (AG), internet kullanımı (INT), patentler (PAT) ve Endüstri 4.0 (END4) ilgi düzeyi değişkenlerinden oluşan açıklayıcı değişken vektörüdür. $\beta$ bir parametre vektörü, $\varepsilon$ hata terimi ve $v$ zamandan bağımsız gözlenmeyen özelliklerdir.

Çalışmada, yüksek teknoloji ithalatını (YTI) ve ihracatını (YTÏH) etkileyen faktörleri belirlemek için dört farklı model geliştirilmiştir. İlk modelde, sadece Endüstri 4.0'a ( $\triangle$ END4) ilgi düzeyinin yüksek teknoloji ithalatı ve ihracatı üzerindeki etkisi incelenmiştir.

Model 1: $\quad Y T \dot{\mathrm{I}}_{i t}$ veya $Y T \dot{\mathrm{I}} H_{i t}=\alpha+\beta_{1} E N D 4_{i t}+\varepsilon_{i t}$

(4)

İkinci modelde, beşeri sermaye (BS), doğrudan yabancı yatırımlar (DYSY), gayri safi yurtiçi tasarruflar (YİT), gayri safi sermaye oluşumu (SO), altyapı (AY), döviz kurları $(\triangle \mathrm{DK})$, enflasyon ( $\triangle \mathrm{ENF})$ ve göç ( $\triangle \mathrm{GÖÇ)}$ değişkenlerinin yüksek teknoloji ithalatı ve ihracatı üzerindeki etkileri incelenmiştir.

Model 2: $\quad Y T \dot{I}_{i t}$ veya $Y T \dot{\mathrm{I}} H_{i t}=\alpha+\beta_{1} B S_{i t}+\beta_{2} D Y S Y_{i t}+\beta_{3} Y \dot{I} T_{i t}+\beta_{4} S O_{i t}+\beta_{5} A Y_{i t}+\beta_{6} D K_{i t}+\beta_{7} E N F_{i t}+$ $\beta_{8} G O ̈ C_{i t}+\varepsilon_{i t}$

(5)

Üçüncü modelde, ikinci modele teknoloji (TEK), Ar-Ge $(\triangle \mathrm{AG})$, internet kullanımı ( $\triangle \mathrm{INT})$ ve patent (PAT) değişkenleri eklenmiştir.

Model 3: $\quad Y T \dot{I}_{i t}$ veya YTİ $H_{i t}=\alpha+\beta_{1} B S_{i t}+\beta_{2} D Y S Y_{i t}+\beta_{3} Y \dot{I} T_{i t}+\beta_{4} S O_{i t}+\beta_{5} A Y_{i t}+\beta_{6} D K_{i t}+\beta_{7} E N F_{i t}+$ $\beta_{8} G O ̈ C_{i t}+\beta_{9} T E K_{i t}+\beta_{10} A G_{i t}+\beta_{11} I N T_{i t}+\beta_{12} P A T_{i t}+\varepsilon_{i t}$

(6)

Son modelde, tüm değişkenlerin etkisi araştırılmıştır.

Model 4: $\quad Y T \dot{\mathrm{I}}_{i t}$ veya $Y T \dot{\mathrm{I}} \mathrm{H}_{i t}=\alpha+\beta_{1} B S_{i t}+\beta_{2} D Y S Y_{i t}+\beta_{3} Y \dot{\mathrm{I}} T_{i t}+\beta_{4} S O_{i t}+\beta_{5} A Y_{i t}+\beta_{6} D K_{i t}+\beta_{7} E N F_{i t}+$ $\beta_{8} G O ̈ C_{i t}+\beta_{9} T E K_{i t}+\beta_{10} A G_{i t}+\beta_{11} I N T_{i t}+\beta_{12} P A T_{i t}+\beta_{13} E N D 4_{i t}+\varepsilon_{i t}$

(7)

\subsection{Yöntem}

Çalışmada kullanılan yöntem panel veri analizidir. Paneli oluşturan kesitler arasında bir bağımlılık olup olmadığını belirlemek için Breusch ve Pagan (1980) LM (Lagrange Multiplier) testi ve Pesaran (2004) tarafından geliştirilen CD (Cross Section Dependent) testi kullanılmıştır. Kesit bağımlılık testlerinden ilki, aşağıda gösterilen Breusch ve Pagan (1980) tarafından geliştirilen Lagrange Çarpanı (LM) testidir.

$$
L M=T \sum_{i=1}^{N-1} \sum_{j=i+1}^{N} \hat{\rho}_{i j}^{2}
$$

$\mathrm{Bu}$ testte $\mathrm{H} 0$ hipotezi, kesitler arasındaki korelasyonu göstermez ve $\mathrm{N}$ sabit ve $\mathrm{T} \rightarrow \infty$ iken $(\mathrm{N}(\mathrm{N}-1)) / 2$ serbestlik derecesinde ki-kare asimptotik dağılıma sahiptir. Testin zaman boyutu T'nin kesit boyutu N'den büyük olduğunda kullanılabileceği varsayılmaktadır (Pesaran, 2004: 4).

Kesit testlerinden ikincisi, Pesaran (2004) tarafından geliştirilen CDLM testidir. Bu test, hem N hem de T'nin büyük olduğu durumlarda uygulanabilir. Bu test, önceki Breusch ve Pagan (1980) testinin geliştirilmiş versiyonudur. Aşağıdaki denklemde gösterilmiştir. Bu teste göre, $T \rightarrow \infty$ ve $N \rightarrow \infty$ ise kesit bağımlılığ olmadığı varsayılır. Bununla birlikte, $\mathrm{N}>\mathrm{T}$ olduğu durumlarda, CDıм testleri önemli ölçüde bozulma göstermektedir.

$$
C D_{L M}=\sqrt{\frac{1}{N(N-1)} \sum_{i=1}^{N-1} \sum_{j=i+1}^{N} \hat{\rho}_{i j}}
$$

Kesit testlerinden üçüncüsü, Pesaran (2004) tarafından geliştirilen CD testidir. Bu test, $\mathrm{N}>\mathrm{T}$ olduğunda yanal kesit bağımlılığı için geliştirilmiştir.

$$
C D=\sqrt{\frac{2 T}{N(N-1)} \sum_{i=1}^{N-1} \sum_{j=i+1}^{N} \hat{\rho}_{i j}}
$$




\section{O. Yavuz 13/1 (2021) 825-843}

Test sonuçlarına göre H0 hipotezinin kabul edilmesi ülkeler arasında kesit bağımlılığı olmadığı anlamına gelmektedir. Ancak H0 hipotezi reddedilir ve ülkeler arasında yatay kesit bağımlılığı varsa bu durumda ikinci nesil panel birim kök testleri ile analize devam edilmelidir (Baltagi, 2008: 284). Bu çalışmada, ayrı ayrı yüksek teknoloji ürünleri ithalatı ve ihracatı bağımlı değişken olduğu durumlarda, Tablo 3 ve Tablo 4'de görülüleceği üzere, LM, CDLM ve CD testlerinde H0 hipotezi reddedilmiş, eşbütünleşme denkleminin olasılık değerleri 0,05'ten küçük olduğu için serilerde kesit bağımlılığı olduğu belirlenmiştir.

Birim kök testleri, enine kesitlerin bağımsız olduğunu varsayar. Kesitsel bağımlılık, gözlemlenmemiş ortak faktörler, dişsallıklar, bölgesel ve ekonomik bağlantılar nedeniyle ortaya çıabilir. İkinci nesil panel birim kök testleri, kesitsel bağımlılık sorununu ele almaktadır. İyi bilinen ve yaygın olarak kullanılan ikinci nesil testlerden birisi, Pesaran (2007) tarafından önerilmiştir. Kesitsel bağımlılıkla bir panel birim kök testi oluşturmak için Pesaran (2007), Kesitsel Artırılmış Dickey-Fuller (CADF) regresyonunu dikkate almaktadır. Seri için birim kök analizi, çapraz kesit bağımlılı̆̆ altında Augmented Dickey Fuller testi ile gerçekleştirilmiştir. Kesit bağımlılığını (CIPS) dikkate alan birim kök testleri, Pesaran (2007) kesitsel olarak artırılmış IPS (CIPS) test istatistiklerine göre hazırlanmıştır.

CIPS testine göre, enflasyon, döviz kurları, göç, Ar-Ge, internet kullanımı ve Endüstri 4.0'a ilgi düzeyi gibi bazı değişkenler, yalnızca sabitli ve trendli ve sabitli dahil edildiğinde durağan değildir. Öte yandan, bu değişkenlerin ilk farklarına birim kök testleri uygulandığında durağan oldukları görülmektedir (Tablo 2).

Panel veri analizinde, eşbütünleşme teknikleri, zaman serilerindeki $(\mathrm{T})$ ve kesitlerdeki $(\mathrm{N})$ değişkenler arasında uzun vadeli bir ilişkinin varlığını test etmek için kullanılmıştır. Bu çalışmada, değişken sayısına bağlı olarak seriler arasında eşbütünleşme ilişkisinin varlığı Kao (1999) panel eşbütünleşme testi ile incelenmiştir. Elde edilen sonuçlara göre hem ithalat hem de ihracat için olasılık değerleri 0.05 'e eşit ya da küçük olduğu için H0 hipotezi reddedilmiş ve seriler arasında eşbütünleşme ilişkisi bulunmaktadır.

Çalışmanın bu aşamasında birim kök testi ve eşbütünleşme testinin belirlenmesinin ardından ülke gruplarına göre sabit ve tesadüfi etki modeli sonuçları belirlenmiştir. Bunun için öncelikle uygun panel veri modeline karar vermek için birim ve zaman etkileri belirlenmiş ve sabit veya karma modeli belirlemek için $\mathrm{F}$ testi; tesadüfi ve sabit etki için Hausman testi uygulanmıştır. Her test tüm modeller için ayrı ayrı uygulanmıştır. Modelin karma model tarafından mı yoksa sabit etkiler modeli tarafından mı tahmin edildiğini belirlemek için F testi sonuçları dikkate alınmıştır. Tablo 3 'deki F testi sonuçları incelendiğinde olasılık değerinin kritik değerin altında olduğu tespit edilmiş ve sıfır hipotezi reddedilmiştir. Bu nedenle, modeli karma model yerine sabit etkiler modeli ile tahmin etmenin daha etkili olacağı belirlenmiştir. Hausman testi, sabit etkiler modeli tutarlı olduğunda tesadüfi etkiler modelinin tutarlı olup olmadığını ve veri seti tesadüfi oluşturulduğunda sabit etkiler modelinin tutarlı olup olmadığını belirlemek için kullanılır. Hausman testi istatistik değeri 0.05 kritik değerin altındaysa, sıfır hipotezi reddedilir. Öte yandan Hausman testi istatistik değeri kritik değerden yüksek ise tesadüfi etkiler modeli tahmin edilir. Hausman testi sonucu incelendiğinde olasılık değerinin kritik değerden yüksek olduğu görülmektedir. Bu nedenle, F testi ve Hausman testi sonuçlarına göre yüksek teknoloji ürünleri ithalatı ile ilgili araştırmada her model için tesadüfi etkiler modeli seçilmiştir.

Tablo 4 incelenecek olursa, yüksek teknoloji ihracatına değişkenlerin etkisi incelenirken farklı olarak, sabit etkiler modeli kullanılmıştır. F testi sonuçları incelendiğinde olasılık değerinin kritik değerin altında olduğu tespit edilmiş ve sıfır hipotezi reddedilmiştir. Bu nedenle, modeli karma model yerine sabit etkiler modeli ile tahmin etmenin daha etkili olacağı belirlenmiştir. Hausman testi sonucu incelendiğinde olasılık değerinin kritik değerden düşük olduğu görülmektedir. Bu nedenle, $\mathrm{F}$ testi ve Hausman testi sonuçlarına göre araştırmada her model için sabit etkiler modeli seçilmiştir. 
Tablo 2. Kesit bağımlılığını dikkate alan birim kök testleri: CIPS testi

\begin{tabular}{|c|c|c|c|c|c|c|c|c|c|c|c|c|c|c|c|c|}
\hline Ülkeler & $\Delta \mathrm{DK}$ & DYSY & SO & YíT & BS & YTí & $\begin{array}{l}\text { YTİ+ } \\
\text { YTİH }\end{array}$ & $\begin{array}{c}\Delta \text { END } \\
4\end{array}$ & $\Delta \mathrm{ENF}$ & AY & $\Delta \mathrm{INT}$ & $\Delta \mathrm{GÖÇ}$ & PAT & $\Delta \mathrm{AG}$ & TEK & YTİH \\
\hline İngiltere & $-3.91^{* *}$ & $2.78^{* * *}$ & -1.99 & $\begin{array}{c}- \\
3.57^{* * *}\end{array}$ & -2.16 & -1.27 & -1.76 & -2.47 & -2.42 & -1.97 & -2.35 & -2.31 & -0.72 & $-3.83^{* *}$ & -1.76 & -2.74 \\
\hline Çek Cum. & $-3.71^{* *}$ & $-5.02^{*}$ & $\begin{array}{c}- \\
2.89^{* * *}\end{array}$ & $\begin{array}{c}- \\
3.71^{* * *}\end{array}$ & -1.64 & -1.25 & -1.55 & -2.63 & $-3.59^{* *}$ & -2.60 & $-7.61^{*}$ & $\begin{array}{c}- \\
3.04^{* * *}\end{array}$ & -1.85 & -2.04 & -0.40 & -1.82 \\
\hline Austurya & $-3.66^{* *}$ & $-5.28^{*}$ & 0.19 & -0.79 & -1.94 & -1.52 & -3.16 & -2.69 & -3.28 & $\begin{array}{c}- \\
2.83^{* * * *}\end{array}$ & $-5.27^{*}$ & -1.50 & -0.66 & $-6.84^{*}$ & -1.91 & -1.30 \\
\hline Belçika & $-3.66^{* *}$ & -1.21 & 1.20 & -3.25 & $-4.10^{* *}$ & -2.05 & $\begin{array}{c}- \\
3.85^{* * *}\end{array}$ & $-3.36^{* *}$ & $\begin{array}{c}- \\
2.98^{* * * *}\end{array}$ & $-3.20^{* *}$ & -2.42 & $\begin{array}{c}- \\
2.93^{* * *} \\
\end{array}$ & -1.05 & $-3.59^{* *}$ & -1.15 & -2.38 \\
\hline Finlandiya & $-3.66^{* *}$ & $-3.84^{* *}$ & -2.42 & -0.07 & -2.64 & -2.18 & -2.54 & -1.87 & $-3.33^{* *}$ & -2.37 & $-3.40^{* *}$ & $\begin{array}{c}- \\
2.99^{* * *}\end{array}$ & -1.57 & -1.92 & -1.94 & -0.85 \\
\hline Fransa & $-3.66^{* *}$ & $-3.37^{* *}$ & 0.58 & -2.71 & -0.15 & -1.79 & $-4.83^{* *}$ & $-2.73^{*}$ & -2.60 & -2.50 & $-3.55^{* *}$ & -1.20 & $\begin{array}{c}- \\
2.91^{* * *}\end{array}$ & -2.46 & -0.91 & -1.44 \\
\hline Almanya & $-3.66^{* *}$ & $\begin{array}{c}- \\
2.81^{* * * *} \\
\end{array}$ & $-4.58^{*}$ & -1.42 & -2.17 & $-4.56^{*}$ & $-4.46^{* *}$ & -1.93 & $\begin{array}{c}- \\
2.91^{* * * *}\end{array}$ & $-4.02^{* *}$ & $-3.79^{* *}$ & -1.08 & -2.14 & $\begin{array}{c}- \\
3.21^{* * *} \\
\end{array}$ & -1.66 & -2.81 \\
\hline Yunanistan & $-3.66^{* *}$ & -1.31 & $-3.78^{* *}$ & $\begin{array}{c}- \\
3.83^{* * *}\end{array}$ & -1.04 & -1.90 & $-4.08^{* *}$ & $-3.93^{* *}$ & $\begin{array}{c}- \\
2.84^{* * * *}\end{array}$ & -1.54 & $-3.25^{* *}$ & -1.28 & -1.21 & $\begin{array}{c}- \\
2.93^{* * *}\end{array}$ & -2.18 & -2.27 \\
\hline İrlanda & $-3.66^{* *}$ & -2.33 & -2.24 & -2.78 & $-3.16^{* *}$ & -1.27 & $-4.53^{* *}$ & -2.29 & -2.57 & $-8.81^{*}$ & $\begin{array}{c}- \\
2.87^{* * *}\end{array}$ & $-3.72^{* *}$ & -0.50 & -1.96 & -1.00 & -2.27 \\
\hline İtalya & $-3.66^{* *}$ & $-9.68^{*}$ & -1.89 & -2.71 & -1.88 & $-7.32^{*}$ & $-6.04^{*}$ & -2.46 & $-4.20^{* *}$ & -1.96 & -1.81 & $-3.59 * *$ & $-3.22^{* *}$ & $\begin{array}{c}- \\
3.07^{* * *} \\
\end{array}$ & $-3.33^{* *}$ & -2.84 \\
\hline Lüksemburg & $-3.66^{* *}$ & $-3.67^{* *}$ & $\begin{array}{c}-3.20 \\
* * \\
\end{array}$ & $-9.26^{*}$ & $-3.09^{* *}$ & -0.93 & -2.08 & $-3.39^{* *}$ & -2.47 & -2.32 & -1.78 & $\begin{array}{c}- \\
2.87^{* * *}\end{array}$ & -2.17 & $-3.38^{* *}$ & -1.06 & -3.06 \\
\hline Hollanda & $-3.66^{* *}$ & $\begin{array}{c}- \\
3.07^{* * *}\end{array}$ & -2.58 & -1.48 & -1.44 & -1.55 & -2.37 & -1.28 & -2.12 & -2.33 & -2.61 & -0.78 & -2.23 & -2.71 & -2.36 & -3.29 \\
\hline Portekiz & $-3.66^{* *}$ & $\begin{array}{c}- \\
2.81^{* * *} \\
\end{array}$ & -1.64 & -3.05 & $\begin{array}{c}- \\
2.75^{* * *} \\
\end{array}$ & $-3.22^{* *}$ & $-4.83^{* *}$ & $-2.74^{* * *}$ & $\begin{array}{c}- \\
2.74^{* * *}\end{array}$ & $-3.61^{* *}$ & -0.31 & -1.41 & -2.33 & $\begin{array}{c}- \\
3.10^{* * * *}\end{array}$ & $-7.98^{*}$ & -1.98 \\
\hline İspanya & $-3.66^{* *}$ & $-3.87^{* *}$ & $-3.39^{* *}$ & -1.77 & 0.47 & $-2.76^{*}$ & $-4.80^{* *}$ & -1.55 & $-3.94^{* *}$ & -2.40 & $-4.85^{*}$ & -2.71 & $\begin{array}{c}-6.92 \\
*\end{array}$ & $\begin{array}{c}- \\
3.08^{* * *}\end{array}$ & $\frac{-}{3.14^{* * *}}$ & -2.43 \\
\hline Danimarka & $-3.61^{* *}$ & $-5.20^{*}$ & 1.40 & -2.80 & -1.28 & $-4.47^{*}$ & $-4.56^{* *}$ & $-2.97^{* * *}$ & -2.42 & -1.78 & -2.10 & -2.17 & -1.77 & $\begin{array}{c}-5.91 \\
*\end{array}$ & -1.91 & -3.24 \\
\hline Estonya & $-3.28^{* *}$ & $\begin{array}{c}- \\
2.98^{* * *} \\
\end{array}$ & $-7.53^{*}$ & $\begin{array}{c}- \\
3.82^{* * *}\end{array}$ & -2.04 & -2.33 & -1.51 & $-2.90^{* * *}$ & $-3.61^{* *}$ & -2.51 & $\begin{array}{c}- \\
2.96^{* * *} \\
\end{array}$ & -2.48 & -1.97 & -2.14 & $-4.71^{*}$ & -0.75 \\
\hline Litvanya & $\begin{array}{c}- \\
3.16^{* * * *}\end{array}$ & $-7.21^{*}$ & $-14.30^{*}$ & -2.49 & -2.42 & $\begin{array}{c}- \\
3.02^{* * *}\end{array}$ & $-6.56^{*}$ & $-3.08^{* * *}$ & $\begin{array}{c}- \\
2.86^{* * * *}\end{array}$ & -1.85 & $-3.73^{* *}$ & $-3.52^{* *}$ & -2.53 & $-3.35^{* *}$ & $-3.78^{* *}$ & -1.81 \\
\hline İsveç & $-3.10^{* *}$ & -2.65 & 2.39 & -0.79 & $-3.59^{* *}$ & $-4.28^{*}$ & -2.25 & -2.46 & -2.57 & -2.66 & $-4.27^{* *}$ & -2.23 & -1.99 & $-3.47^{* *}$ & -2.02 & $\begin{array}{c}- \\
3.57^{* * * *}\end{array}$ \\
\hline Norveç & -2.50 & 0.58 & -1.11 & $-4.39^{* *}$ & 0.16 & -2.66 & -0.87 & $-4.01^{* *}$ & $-4.67^{*}$ & $-3.93^{* *}$ & $-3.68^{* *}$ & 0.65 & -2.44 & -2.57 & -0.28 & $-4.88^{* *}$ \\
\hline
\end{tabular}


O. Yavuz 13/1 (2021) 825-843

\begin{tabular}{|c|c|c|c|c|c|c|c|c|c|c|c|c|c|c|c|c|}
\hline \multicolumn{17}{|c|}{ Tablonun Devamı... } \\
\hline Letonya & -2.26 & $-4.08^{* *}$ & -1.83 & $\begin{array}{c}- \\
3.84^{* * *}\end{array}$ & $-3.58^{* *}$ & 1.13 & $-5.39^{*}$ & -1.00 & -2.71 & $-3.31^{* *}$ & -2.21 & -2.58 & -1.48 & $\begin{array}{c}- \\
3.03^{* * *}\end{array}$ & -2.33 & -2.60 \\
\hline Slovakya & -2.67 & $-3.39^{* *}$ & $\begin{array}{c}- \\
2.89^{* * *} \\
\end{array}$ & -3.04 & $-6.46^{*}$ & -1.26 & $-4.31^{* *}$ & -1.51 & $\begin{array}{c}- \\
2.76^{* * *}\end{array}$ & $\begin{array}{c}- \\
2.81^{1 * *}\end{array}$ & -3.02 & -2.40 & $-6.92^{*}$ & $\begin{array}{c}- \\
3.02^{* * *}\end{array}$ & -1.19 & -1.08 \\
\hline Bulgaristan & $-3.62^{* *}$ & $-7.86^{*}$ & -1.73 & -2.98 & $-3.32^{* *}$ & -0.96 & $-4.30^{* *}$ & -1.93 & -2.59 & -1.95 & $-5.24^{*}$ & -1.98 & $-3.99 * *$ & $\begin{array}{c}- \\
2.80^{* * *}\end{array}$ & $\begin{array}{c}- \\
2.80^{* * *}\end{array}$ & -1.02 \\
\hline Kanada & -2.23 & $-4.13^{* *}$ & $\begin{array}{c}- \\
2.94^{* * *}\end{array}$ & $-4.18^{* *}$ & 0.29 & $\begin{array}{c}- \\
3.05^{* * *}\end{array}$ & $-10.58^{*}$ & -1.95 & -2.53 & $-5.29^{*}$ & $-3.62^{* *}$ & $-3.49^{* *}$ & -0.67 & $-4.73^{*}$ & -1.12 & -2.60 \\
\hline Hirvatistan & $-3.60^{* *}$ & $\begin{array}{c}- \\
3.01^{* * *}\end{array}$ & -1.97 & -2.45 & -1.55 & 0.98 & -2.84 & $-3.05^{* * *}$ & $\begin{array}{c}- \\
3.07^{* * *}\end{array}$ & -1.79 & $-3.23^{* *}$ & -0.68 & -2.53 & $-3.35^{* *}$ & $-8.96^{*}$ & $-7.59^{*}$ \\
\hline Macaristan & $\begin{array}{c}- \\
2.93^{* * *} \\
\end{array}$ & $-3.37^{* *}$ & -1.48 & $\begin{array}{c}- \\
3.69^{* * *}\end{array}$ & -1.11 & -0.73 & -2.10 & -2.07 & $\begin{array}{c}- \\
2.97^{* * *}\end{array}$ & -2.08 & -0.75 & $\begin{array}{c}- \\
3.01^{1 * *}\end{array}$ & -0.95 & $-3.40^{* *}$ & -1.70 & $\begin{array}{c}- \\
3.52^{* * *}\end{array}$ \\
\hline Japonya & -2.43 & -2.24 & -1.82 & -1.44 & -1.76 & -1.16 & -2.57 & -2.40 & -0.59 & -2.59 & -2.04 & -0.99 & -1.92 & -2.66 & -1.91 & $-4.53^{* *}$ \\
\hline Polonya & $-3.32^{* *}$ & $-3.47^{* * *}$ & -2.23 & $-4.64^{* *}$ & $-4.68^{*}$ & $-3.88^{* *}$ & -2.92 & -1.34 & $\begin{array}{c}- \\
3.18^{* * *}\end{array}$ & -1.34 & $\begin{array}{c}- \\
3.19^{* * *}\end{array}$ & -1.45 & -1.74 & $-5.05^{*}$ & -0.89 & -1.91 \\
\hline Romanya & $-3.55^{* *}$ & -2.00 & -1.34 & -1.40 & -1.23 & -1.03 & $-7.46^{*}$ & -2.10 & $\begin{array}{c}- \\
2.76^{* * *} \\
\end{array}$ & -1.25 & $\begin{array}{c}- \\
3.04^{* * *}\end{array}$ & $-3.63^{* *}$ & -2.22 & $-3.30^{* *}$ & -1.89 & $\begin{array}{c}- \\
3.53^{* * *}\end{array}$ \\
\hline Rusya & $\begin{array}{c}- \\
2.81^{* * *}\end{array}$ & -1.45 & $-7.40^{*}$ & $-5.18^{*}$ & -1.61 & -0.53 & -1.79 & -0.81 & $-3.37^{* *}$ & -1.92 & -1.97 & $\begin{array}{c}- \\
3.15^{* * *}\end{array}$ & $-3.45^{* *}$ & $-3.87^{* *}$ & 0.43 & -2.26 \\
\hline Türkiye & 2.050 & $-6.31^{*}$ & -2.44 & -1.58 & -2.20 & -2.50 & -2.97 & -1.86 & -1.99 & 0.19 & -2.06 & $\begin{array}{c}- \\
2.91^{* * *}\end{array}$ & 1.38 & $-4.45^{*}$ & $\begin{array}{c}- \\
2.95^{* * *}\end{array}$ & $-4.25^{* *}$ \\
\hline Amerika & & -2.45 & -2.68 & -2.74 & -0.66 & -1.63 & -1.70 & -1.36 & $-3.43^{* *}$ & $\begin{array}{c}- \\
3.18^{* * *}\end{array}$ & -2.84 & $-3.59^{* *}$ & -0.36 & $-3.95^{* *}$ & $-4.58^{*}$ & -2.22 \\
\hline $1 \%$ & -4.29 & -4.29 & -4.29 & -5.12 & -4.29 & -4.29 & -5.12 & -4.29 & -4.29 & -4.29 & -4.29 & -4.29 & -4.29 & -4.42 & -4.29 & -5.12 \\
\hline $5 \%$ & -3.21 & -3.21 & -3.21 & -3.93 & -3.21 & -3.21 & -3.93 & -3.21 & -3.21 & -3.21 & -3.21 & -3.21 & -3.21 & -3.25 & -3.21 & -3.93 \\
\hline $10 \%$ & -2.74 & -2.74 & -2.74 & -3.42 & -2.74 & -2.74 & -3.42 & -2.74 & -2.74 & -2.74 & -2.74 & -2.74 & -2.74 & -2.77 & -2.74 & -3.42 \\
\hline $\begin{array}{l}\text { CIPS } \\
\text { (Panel } \\
\text { Geneli) } \\
\text { Test İstatist }\end{array}$ & $-3.15^{*}$ & $-3.62^{*}$ & $-2.53^{*}$ & $-2.96^{* *}$ & $\begin{array}{c}- \\
2.09^{* * *}\end{array}$ & $\begin{array}{c}- \\
2.09^{* * *}\end{array}$ & $-3.73^{*}$ & $-2.33^{* *}$ & $-2.91^{*}$ & $-2.66^{*}$ & $-3.09^{*}$ & $-2.29^{* *}$ & $\begin{array}{c}- \\
2.10^{* * *}\end{array}$ & $-3.39^{*}$ & $-2.37^{* *}$ & $\begin{array}{c}- \\
2.67^{* * *}\end{array}$ \\
\hline $1 \%$ & -2.44 & -2.44 & -2.44 & -3.1 & -2.44 & -2.44 & -3.1 & -2.44 & -2.44 & -2.44 & -2.44 & -2.44 & -2.44 & -2.44 & -2.44 & -3.1 \\
\hline $5 \%$ & -2.22 & -2.22 & -2.22 & -2.82 & -2.22 & -2.22 & -2.82 & -2.22 & -2.22 & -2.22 & -2.22 & -2.22 & -2.22 & -2.22 & -2.22 & -2.82 \\
\hline $10 \%$ & -2.1 & -2.1 & -2.1 & -2.67 & -2.1 & -2.1 & -2.67 & -2.1 & -2.1 & -2.1 & -2.1 & -2.1 & -2.1 & -2.1 & -2.1 & -2.67 \\
\hline & C & A & A & B & A & A & B & C & C & A & C & C & A & C & A & B \\
\hline
\end{tabular}

Not: Pesaran (2007) kesitsel olarak artırılmış IPS (CIPS) test istatistiklerine göre hazırlanmıştır. A, Sabitli, B Trendli ve sabitli durumu belirtir ve C, Sabitli 1. farkı ifade etmektedir. 


\subsection{Bulgular}

Çalışma yüksek teknoloji ürünleri ithalatı ve ihracatına etki eden faktörlerin belirlenmesi açısından iki kısımdan oluşmaktadır. Panel veri analizinde birinci kısımda yüksek teknoloji ürünleri ithalatını etkileyen faktörler; ikinci kısımda yüksek teknoloji ürünleri ihracatını etkileyen faktörler belirlenmeye çalışılmıştır. Temel olarak, ikinci kısımda elde edilen sonuçlar daha önemli gibi görünmesine karşın, birinci kısımda elde edilen sonuçlarında da dolaylı olarak yüksek teknoloji ürünleri iharacatını uzun vadede etkileyebileceği düşünülmektedir. Tablo 3, birinci kısımda oluşturulan ampirik model için dört farklı alternatif modelin tahminlerini vermektedir. Tüm modeller, yüksek teknoloji ithalatı için tesadüfi etkilerle tahmin edilmiştir. İlk modelde, Endüstri 4.0'in $(\Delta \mathrm{END} 4)$ yüksek teknoloji ithalatı üzerindeki etkisi incelenmiştir. Endüstri 4.0'ın popülerliği ile yüksek teknoloji ithalatı arasında istatistiksel olarak anlamlı bir ilişki bulunmuştur. Model 1, diğer faktörleri dikkate almadan, Endüstri 4.0'ın popülaritesinin yüksek teknoloji ithalatının \% 0.326'lık bir artışla ilişkili olduğunu göstermektedir (Model 1). Bu sonuç, uluslararası ticaretin ekonomiler arasında bilgi aktarımının hızının artmasına katkıda bulunduğu ve sonuç olarak Endüstri 4.0 faaliyetlerinin artmasına katkıda bulunduğu ve dolayısıyla yüksek teknoloji ithalatını artırdığı görüşünü doğrulamaktadır.

Tablo 3. Panel veri modeli tahmin sonuçları (İthalat)

\begin{tabular}{|c|c|c|c|c|}
\hline Değişkenler & MODEL 1 & MODEL 2 & MODEL 3 & MODEL 4 \\
\hline Sabit Katsay1 & $27.053^{* * *}(15.648)$ & $25.068(1.636)$ & $17.414(1.175)$ & $8.958(0.591)$ \\
\hline BS & & $-0.101(-0.527)$ & $-0.138(-0.753)$ & $-0.029(-0.151)$ \\
\hline DYSY & & $0.0089(0.374)$ & $0.0012(0.042)$ & $0.0027(0.098)$ \\
\hline YİT & & $0.340^{* * *}(3.134)$ & $0.261^{* * *}(2.264)$ & $0.259^{* * *}(2.266)$ \\
\hline $\mathrm{SO}$ & & $0.104(0.924)$ & $0.181(1.596)$ & $0.179(1.592)$ \\
\hline$\triangle \mathrm{ENF}$ & & $-0.420(-0.278)$ & $0.575(0.347)$ & $0.794(0.484)$ \\
\hline$\Delta \mathrm{DK}$ & & $0.052(0.944)$ & $0.011(0.209)$ & $0.0018(0.033)$ \\
\hline AY & & $-0.215(-1.542)$ & $-0.086(-0.601)$ & $0.012(0.083)$ \\
\hline$\Delta \mathrm{GÖÇ}$ & & $8.017(1.358)$ & $6.967(1.191)$ & $6.468(1.115)$ \\
\hline TEK & & & $0.217^{* * *}(3.585)$ & $0.202^{* * *}(3.343)$ \\
\hline$\Delta \mathrm{AG}$ & & & $-1.072(-0.447)$ & $0.078(0.032)$ \\
\hline$\Delta \mathrm{INT}$ & & & $-0.082(-0.862)$ & $-0.062(-0.655)$ \\
\hline PAT & & & $0.00005^{* * *}(2.504)$ & $0.00004^{* * *}(2.399)$ \\
\hline$\triangle \mathrm{END} 4$ & $0.326^{* * *}(3.693)$ & & & $0.248^{* * *}(2.389)$ \\
\hline YTİ + YTİH & & $0.004(0.221)$ & $0.014(0.775)$ & $0.011(0.599)$ \\
\hline R-kare & 0.039954 & 0.092456 & 0.170699 & 0.186013 \\
\hline Düzeltilmiş R-kare & 0.034273 & 0.066192 & 0.132196 & 0.145168 \\
\hline $\begin{array}{l}\text { Regresyonun standard } \\
\text { hatası }\end{array}$ & 3.917753 & 3.733604 & 3.637799 & 3.60509 \\
\hline F-istatistik & 7.033214 & 3.520332 & 4.433377 & 4.554098 \\
\hline Olasıllk(F-istatistik) & 0.001017 & 0.00036 & 0.000001 & 0.0000 \\
\hline Breusch-Pagan LM: & $1058.077(0.000)$ & & & \\
\hline Pesaran ölçekli LM: & $18.43124(0.000)$ & & & \\
\hline Pesaran CD & $12.59988(0.000)$ & & & \\
\hline \multicolumn{5}{|c|}{ Kao Artan Eşbütünleşme Testi: $\quad-1.60857$ (0.0539) } \\
\hline \multicolumn{5}{|c|}{ İlişkili Rastlantısal Etkiler - Hausman Test: 19.9647 (0.1733) } \\
\hline Model: Tesadüfi Etkiler & & & & \\
\hline
\end{tabular}

İkinci modelde, yüksek teknoloji ithalatı ile gayri safi yurtiçi tasarruf arasında istatistiksel olarak anlamlı sonuçlar elde edilmiştir. Diğer değişkenler üzerindeki katsayılar negatif ve önemsizdir. Sonuç olarak, yüksek teknoloji ithalatının beşeri sermaye (BS), doğrudan yabancı yatırımlar (DYSY), gayri safi sermaye oluşumu (SO), altyap1 (AY), döviz kurları $(\Delta \mathrm{DK})$, enflasyon $(\triangle \mathrm{ENF})$ ve göç ( $\triangle \mathrm{GÖÇ)} \mathrm{üzerindeki} \mathrm{dalgalanmalara} \mathrm{yanıt} \mathrm{vermediğini}$ 


\section{O. Yavuz 13/1 (2021) 825-843}

göstermektedir (Model 2). Sonuçlar, yüksek teknoloji ithalatının, genellikle döviz kurlarındaki oynaklık, enflasyon ile ilişkili makroekonomik dalgalanmalar ve beşeri sermaye (BS), doğrudan yabancı yatırımlar (DYSY), gayri safi sermaye oluşumu (SO), altyapı (AY) ve göç ( $\triangle \mathrm{GÖÇ)} \mathrm{gibi} \mathrm{diğer} \mathrm{temel} \mathrm{ekonomik} \mathrm{yapılar} \mathrm{yerine,} \mathrm{gayri} \mathrm{safi}$ yurtiçi tasarrufları temel ekonomik yapı olarak belirlendiğini ortaya koymaktadır.

Üçüncü modelde, teknoloji ve inovasyona ilişkin değişkenler eklendiğinde, gayri safi yurtiçi tasarruf, teknoloji ve patent değişkenleri ile yüksek teknoloji ithalatı arasında anlamlı bir ilişki olduğu sonucuna varılmıştır (Model 3). Son modelde, tüm değişkenlerin etkisi araştırılmıştır. Üçüncü modelin yanı sıra Endüstri 4.0 ( $\Delta$ END4) değişkeninin popülerliğinin de yüksek teknoloji ithalatını etkilediği görülmektedir. Yüksek teknoloji ithalatı ile Endüstri 4.0'ın popülaritesi arasında istatistiksel olarak anlamlı ve pozitif yönde bir ilişki olduğu sonucu elde edilmiştir. Endüstri 4.0'ın popülaritesindeki \%1 birimlik bir artışın yüksek teknoloji ithalatında \% 0.248'lik bir artışa sebep olduğu görülmektedir (Model 4). Bu durumda seçilmiş ülkelerde üretimde kullanılan Endüstri 4.0 bileşenlerine olan artan ilgi düzeyi, yüksek teknoloji ithalatını artırmaktadır.

Çalışmanın ikinci kısmında, yüksek teknoloji ürünleri ihracatını etkileyen faktörler panel veri analizi ile belirlenmeye çalışılmış ve birinci kısımda olduğu gibi dört farklı model geliştirilmiştir (Tablo 4). Tüm modeler, sabit etkilerle tahmin edilmiştir. Birinci modelde, sadece Endüstri 4.0'a olan ilgi düzeyi ( $\mathrm{END} 4)$ araştırılmıştır. Diğer değişkenler dikkate alınmadan, Endüstri 4.0'a olan ilgi düzeyi ile yüksek teknoloji ihracatı arasında istatistiksel olarak anlamlı bir ilişki bulunmamıştır (Model 1). Temel ekonomik faktörlerin değerlendirildiği ikinci modelde, yüksek teknoloji ihracatı ile beşeri sermaye (BS) ve gayri safi yurtiçi tasarruf (YİT) değişkenleri dışında diğer faktörlerin istatistiksel olarak anlamlı bir etkisinin olmadığı görülmektedir (Model 2). Endüstri 4.0'a olan ilgi düzeyinin dahil edilmediği, teknolojiye yönelik değişkenlerin ilave edildiği üçüncü modelde hem ekonomik hem de teknolojik faktörlerin yüksek teknoloji ürünleri ihracatına etkisi incelenmek istenmiştir. Sonuçlara göre, hem gayri safi yurt içi tasarruf (YİT), hemde Ar-Ge harcamalarının (AG) yüksek teknoloji ürünleri ihracatı üzerinde istatistiksel olarak anlamlı ve pozitif bir etkisinin olduğu görülmektedir. Patent (PAT) sayılarının ise etkilediği, ancak negatif yönde etkilediği sonucuna varılmaktadır (Model 3). Üçüncü modele ilave olarak Endüstri 4.0'a ilgi düzeyinin de incelendiği dördüncü modelde ise, üçüncü modelle aynı sonuçlar elde edilmiştir. Model 1'de de belirtildiği gibi, Endüstri 4.0'a olan ilgi düzeyi ile yüksek teknoloji ihracatı arasında istatistiksel olarak anlamlı bir ilişki bulunmamıştır. Diğer taraftan, Ar-Ge harcamalarındaki \%1 birimlik bir artışın yüksek teknoloji ürünleri ihracatında \% 7.275 birimlik bir artışa sebep olduğu görülmektedir. Dolayısıyla, içerisinde Türkiye'nin de bulunduğu seçilmiş ülkeler açısından yüksek teknoloji ürünleri ihracatını artırmanın en etkili yolunun Ar-Ge harcamaları olduğu sonucuna varılmaktadır.

Tablo 4. Panel veri modeli tahmin sonuçları (İhracat)

\begin{tabular}{lllll}
\hline Değişken & MODEL 1 & MODEL 2 & MODEL 3 & MODEL 4 \\
\hline Sabit Katsay1 & $20.904^{* * *}(60.931)$ & $-41.506^{* * *}(-2.151)$ & $-16.670(-0.781)$ & $-21.325(-0.965)$ \\
\hline BS & & $0.707^{* * *}(2.952)$ & $0.378(1.432)$ & $0.440(1.599)$ \\
\hline DYSY & $0.0254(0.942)$ & $-0.0036(-0.111)$ & $-0.0033(-0.101)$ \\
\hline YíT & $0.216^{*}(1.688)$ & $0.409^{* * *}(2.782)$ & $0.409^{* * *}(2.782)$ \\
\hline SO & $-0.079(-0.617)$ & $-0.074(-0.545)$ & $-0.075(-0.557)$ \\
\hline$\Delta$ ENF & $-0.867(-0.510)$ & $0.094(0.050)$ & $0.193(0.101)$ \\
\hline$\Delta$ DK & $0.016(0.256)$ & $-0.033(-0.514)$ & $-0.036(-0.574)$ \\
\hline AY & $-0.184(-1.162)$ & $-0.127(-0.755)$ & $-0.090(-0.516)$ \\
\hline$\Delta$ GÖÇ & $3.443(0.519)$ & $4.640(0.687)$ & $4.435(0.655)$ \\
\hline TEK & & $0.022(0.259)$ & $0.016(0.189)$ \\
\hline$\Delta$ AG & & $6.841^{* * *}(2.464)$ & $7.275^{* * *}(2.572)$ \\
\hline$\Delta$ INT & & $-0.0162(-0.143)$ & $-0.0079(-0.070)$ \\
\hline PAT & & $-0.00010^{* * *}(-2.029)$ & $-0.00011^{* * *}(-2.095)$ \\
\hline$\Delta$ END4 & & & $0.101(0.812)$ \\
\hline YTİ + YTíH & $0.0364(1.379)$ & $0.0077(0.268)$ & $0.0057(0.198)$ \\
\hline
\end{tabular}


O. Yavuz 13/1 (2021) 825-843

\begin{tabular}{|c|c|c|c|c|}
\hline R-kare & 0.91487 & 0.9232 & 0.9294 & 0.929587 \\
\hline $\begin{array}{l}\text { Regresyonun } \\
\text { standard hatas1 }\end{array}$ & 4.385978 & 4.19235 & 4.120483 & 4.123295 \\
\hline $\begin{array}{l}\text { Artıkların } \\
\text { karelerinin toplamı }\end{array}$ & 5924.936 & 4938.799 & 4244.595 & 4233.389 \\
\hline Log olasılık & -970.643 & -894.196 & -809.632 & -809.243 \\
\hline F-istatistiği & 103.4377 & 86.61179 & 76.53705 & 74.71057 \\
\hline $\begin{array}{l}\text { Olasıllık(F- } \\
\text { istatistiği) }\end{array}$ & $(0.0000)$ & $(0.0000)$ & $(0.0000)$ & $(0.0000)$ \\
\hline \multicolumn{5}{|c|}{ Breusch-Pagan LM: 1068.531 (0.0000) } \\
\hline \multicolumn{5}{|c|}{ Pesaran ölçekli LM: 18.77403 (0.0000) } \\
\hline \multicolumn{5}{|c|}{ Pesaran CD: 3.056278 (0.0022) } \\
\hline \multicolumn{5}{|c|}{ Kao Artan Eşbütünleşme Testi: -2.116966 (0.0171) } \\
\hline \multicolumn{5}{|c|}{ İlişkili Rastlantısal Etkiler - Hausman Test: 47.900528 (0.0000) } \\
\hline Model: Sabit Etki & & & & \\
\hline
\end{tabular}

\section{Sonuç ve Tartışma}

İşletmelerin katma değeri yüksek ürünler üretebilmeleri için gerekli olan en önemli faktörlerden birisi yüksek teknoloji ürünleridir. Faktör donatımı teorisi çerçevesinde ülkeler ihtiyaç duydukları yüksek teknoloji ürünlerini başka ülkelerden ithal etmekte, yada ürettikleri ürünleri ihraç etmektedirler. Diğer taraftan, son yıllarda üretimde kullanılan Endüstri 4.0 bileşenlerinin işletmeler tarafından daha fazla kullanılıyor olması, yüksek teknoloji ürünlerine olan ihtiyacı artırmaktadır. Ülke ekonomileri açısından Endüstri 4.0 bileşenlerine olan talep arttıkça üretilen ve ihraç edilen, aynı zamanda ihtiyaç duyulan ve ithal edilen yüksek teknoloji ürünleri artmaktadır.

Çalışmada, 2007-2019 yılları arasındaki veri seti kullanılarak gerçekleştirilen panel veri analizi sonucunda, seçilmiş ülkelerde yüksek teknoloji ürünleri ihracatını etkileyen faktörlerin gayri safi yurt içi tasarruf, Ar-Ge harcamaları ve patent sayıları olduğu tespit edilmektedir. Endüstri 4.0'a olan ilgi düzeyinin ise yüksek teknoloji ürünleri ihracatına doğrudan bir etkisinin olmadığı saptanmaktadır. Beşeri sermaye, doğrudan yabancı yatırımlar, gayri safi yurtiçi tasarruflar, gayri safi sermaye oluşumu, altyapı, döviz kurları, enflasyon ve göç gibi ekonomik değişkenler içerisinde gayri safi yurt içi tasarruf ve beşeri sermayenin yüksek teknoloji ürünleri ihracatını etkilediği görülmektedir. Tebaldi (2011:348, 352), çalışmasında yüksek teknoloji ürünleri ihracatı (çalışan başına) ile beşeri sermaye (25 yaş ve üzerinde ortalama eğitim durumu), doğrudan yabancı sermaye yatırımı ve ithalat ve ihracat rakamlarının toplamı arasında anlamlı bir ilişki bulmuş ve yüksek teknoloji faaliyetlerinin fiziksel sermaye yoğun değil, insan sermayesi yoğun olduğu görüşünü ortaya koymuştur. Çalışmadan elde edilen bulgular, hem fiziksel sermayenin (gayri safi yurt içi tasarruf) hemde beşeri sermayenin yüksek teknoloji üretimi ve ihracatı açısından önemli olduğu sonucunu göstermektedir. Sonuçlar, işletmelerin beşeri ve fiziksel sermaye oluşturarak ekonomik büyümeyi artırabileceği fikrini savunan Jones (1995:501)'un çalışması ile paralellik göstermektedir.

Teknolojik değişkenler açısından ele alındığında, seçilmiş ülkeler ve panel veri analizi sonuçlarına göre, teknoloji, Ar-Ge harcamaları, internet kullanımı ve patent sayıları değişkenleri arasında patent ve Ar-Ge harcamalarının yüksek teknoloji ürünleri ihracatı üzerinde etkisinin olduğu görülmektedir. En fazla etkinin Ar-Ge harcamaları ile olduğu görülmektedir. Çalışmadan elde edilen bulguların, Özer ve Çiftçi (2009), Yıldırım ve Kesikoğlu (2012), Sandu ve Ciocanel (2014) ve Göçer (2013) tarafından elde edilen sonuçlarla tutarlı olduğu görülmektedir.

Çalışmada, üretimde kullanılan bulut bilişim, nesnelerin interneti, büyük veri analitiği, eklemeli üretim, robotik sistemler, artırılmış gerçeklik, similasyon, yatay ve dikey sistem entegrasyonu ve siber-güvenlik unsurlarından oluşan Endüstri 4.0'a olan ilgi düzeyi ile yüksek teknoloji ürünleri ihracatı arasında istatistiksel olarak anlamlı bir ilişki olmadığı tespit edilmiştir. Diğer taraftan, yüksek teknoloji ürünleri ithalatı ile anlamlı bir ilişki olduğu görülmektedir. Ülkelerin yüksek teknoloji ithalatı daha çok gayri safi yurt içi tasarruf, teknoloji, patent ve Endüstri 


\section{O. Yavuz 13/1 (2021) 825-843}

4.0'a olan ilgi düzeyinden etkilenmektedir. Dolayısıyla seçilmiş ülkeler açısından ve 2007-2019 yılları arasındaki verilerle elde edilen souçlara göre, Ar-Ge harcamalarının yüksek teknoloji ürünleri ihracatını arttırdığı, ithalat üzerinde bir etkisinin olmadığ1; tam tersi, Endüstri 4.0'a olan ilgi düzeyinin yüksek teknoloji ürünleri ithalatını artırdığı, ihracat üzerinde bir etkisinin olmadığı görülmektedir.

Sonuç olarak, sürdürülebilir kalkınma gerçekleştirmek isteyen ülkelerin yüksek teknoloji ürünleri üretebilmeleri ve bu ürünleri başka pazarlara ihraç edebilmeleri gerekmektedir. Yüksek teknoloji ürünleri ihracatının artırılabilmesi için Ar-Ge faaliyetlerinin artırılması gerekmektedir (Özer ve Çiftçi, 2009: Yıldırım ve Kesikoğlu, 2012: Sandu ve Ciocanel, 2014: Göçer, 2013). Üretimde kullanılan Endüstri 4.0 araçlarına olan ilgi düzeyinin henüz Ar-Ge faaliyetlerine yansımadığı görülmekte, bu araçların ülke pazarlarında gerekli beşeri ve fiziksel sermaye yatırımlarıyla (gayri safi yurt içi tasarruf) beraber Ar-Ge faaliyetlerinin bir parçası haline dönüştürülmesi gerekmektedir. Elde edilen sonuçlar daha önce gerçekleştirilen çalışmalarla tutarlıdır (Tebaldi, 2011: Jones, 1995: Švarcová vd., 2019: Monostori, 2014, Muscio ve Ciffolilli, 2019). Švarcová vd. (2019), çalışmalarında Almanya endüstrisi içi önemli bir alt yüklenici olan Çek Cumhuriyetinin teknik bilimlerde güçlü bir Ar-Ge personeline sahip olmasına ragmen, Endüstri 4.0 projelerinin geliştirilebilmesi için beşeri sermaye yatırımlarının artırılması ve böylece Ar-Ge personelinin geliştirilmesi gerektiği sonucuna ulaşmışlardır. Muscio ve Ciffolilli (2019: 174) Endüstri 4.0 teknolojileri ile ilgili Avrupa Birliği destekli gerçekleştirilen Ar-Ge projelerini incelemiş ve en fazla proje gerçekleştiren ülkelerin Almanya, İngiltere, İtalya, İspanya, Fransa, Hollanda, İsviçre, Yunanistan, Avusturya ve İsveç olduğunu göstermiş̧ir. Yazarlara göre beşeri ve fiziksel yatırımlar Endüstri 4.0 gibi teknolojilerinin gelişmesini sağlamaktadır. Koyuncu ve Balan (2020: 9), “Ar-Ge harcamalarının artırılarak Ar-Ge faaliyetlerine gereken önemin verilmesi, teknolojik alt yapının geliştirilmesine yönelik yatırımların gerçekleştirilmesi, teknolojik gelişim için tekno kentlerin sayısının artırılması ve tüm bu gelişmelerin ardındaki beşeri sermaye sahibi araştırmacılara mali desteklerin sağlanması durumunda emeğin Endüstri 4.0 sürecine uyum sağlamasının daha kolay olabileceği" belirtmektedir. Son yıllarda hem işletme bazında hem de ülke ekonomileri açısından Endüstri 4.0 araçlarına olan ilgi düzeyinin arttığı görülmektedir. Bu ilgi düzeyinin teknoloji transferi ile yüksek teknoloji ürünlerin üretiminin artırılmasında kullanılması durumunda, yeni tüketim malları, yeni üretim veya teslimat yöntemleri ve yeni pazarlar bulunması durumunda dolaylı olarak ihracat rakamları üzerinde etkili olacağı düşünülmektedir.

Monostori (2014), işletmelerde özellikle üretim süreçlerinde Ar-Ge faaliyetlerinde karşılaşılan sorunları belirtmekte ve bu sorunların Endüstri 4.0 araçları ile giderilebileceğini öne sürmektedir. Türkiye gibi gelişmekte olan ülkelerin Endüstri 4.0 teknolojilerine olan ilgi düzeyini Ar-Ge faaliyetlerine dönüştürmesi ve yaşanan sorunlara pratik çözümler üretmesi gerekmektedir. Ar-Ge faaliyetleri ile Endüstri 4.0 arasındaki ilişki ise ayrı bir çalışma konusu olarak görülmektedir. Bu açıdan çalışma ilerde gerçekleştirilecek çalışmalara ışık tutmaktadır.

\section{Kaynakça}

Aktura, B. (2020). Aile hekimliği merkezlerinde pandemi yönetimi. The Journal of Turkish Family Physician, 11(1), 45-47.

Akyol, M., ve Demez, S. (2020). İnovasyonun yüksek teknoloji ürün ihracati üzerindeki etkisi: yeni endüstrileşen ülkeler için panel veri analizi. Journal of Yaşar University, 15(57), 56-62.

Anoruo, E. ve DiPietro, W. R., (2006). Creativity, innovation, and export performance, Journal of Policy Modeling, 28(2), 133-139.

Aydin, E. Impact of capital intensity and R\&D spending on manufacturing industry value added in Industry 4.0 process: panel data analysis. Yönetim ve Ekonomi Araştırmaları Dergisi, 16(1), 303-314.

Bahrin, M. A. K., Othman, M. F., Azli, N. H. N. ve Talib, M. F. (2016). Industry 4.0: A review on industrial automation and robotic. Jurnal Teknologi, 78(6-13).

Balıkçığlu, E., ve Çoban, H. (2020). Güven, inovasyon ve ekonomik büyüme ilişkisi. Maliye Araştırmaları Dergisi, 6(3), 77-92. 


\section{O. Yavuz 13/1 (2021) 825-843}

Baltagi, B. (2008). Econometric Analysis of Panel Data, John Wiley \& Sons, Fourth Edition.

Barro, R. J. ve Lee, J. W. (2010). A New Data Set of Educational Attainment in the World, 1950-2010. NBER Working Paper No. 15902. National Bureau of Economic Research.

Bolkan, E., ve Kaplan, F. (2020). Teknoloji yoğun malların sektörel ihracatı: Türkiye örneği. Atatürk Üniversitesi İktisadi ve İdari Bilimler Dergisi, 34(3), 1001-1020.

Braunerhjelm, P. ve Thulin, P. (2008). Can countries create comparative advantages? R\&D expenditures, high-tech exports and country size in 19 OECD countries, 1981-1999. International Economic Journal, 22(1), 95-111.

Breusch, T. S. ve Pagan, A. R. (1980). The Lagrange multiplier test and its applications to model specification in econometrics. The Review of Economic Studies, 47(1), 239-253.

Cheng, L. K. ve Dinopoulos, E. (1992). Schumpeterian growth and international business cycles. The American Economic Review, 82(2), 409-414.

Çetin, R. (2016). Yeni sanayileşen ülkelerde ar-ge harcamaları ve yüksek teknoloji ürünü ihracatı arasındaki ilişkinin panel veri analizi yöntemi ile incelenmesi, İktisat Fakültesi Mecmuası, 66(2), 30-43.

D'Angelo, A. (2012). Innovation and export performance: a study of Italian high-tech SMEs. Journal of Management \& Governance, 16(3), 393-423.

Dereli, D. D. (2019). The relationship between high-technology exports, patent and economic growth in Turkey (1990-2015). Journal of Business Economics and Finance, 8(3), 173-180.

Eaton, J. ve Kortum, S. (2002). Technology, geography, and trade. Econometrica, 70(5), 1741-1779.

Erdil, E., Turkcan, B ve Yetkiner, İ. H. (2009). Does information and communication technology sustain economic growth ? The underdeveloped and developing countries case, Science And Technology Policies Research Center, TEKPOL Working Paper Series 09/03, 1-15

Erkişi, K., ve Boğa, S. (2019). High-technology products export and economic growth: A panel data analysis for EU-15 countries, Bingöl Üniversitesi Sosyal Bilimler Enstitüsü Dergisi, 18(9), 669-682

Falk, M. (2009). High-tech exports and economic growth in industrialized countries, Applied Economics Letters, 16(10), 1025-1028

Gaberli, Ü. (2018). G7 ülkelerinde fikri mülkiyet haklarına yapılan ödemeler ve ar-ge harcamalarının yüksek teknoloji ihracatına etkisi: bir panel veri analizi. Finans Politik \& Ekonomik Yorumlar, 55(641), 67-82.

Göçer, İ. (2013). Ar-Ge harcamalarının yüksek teknolojili ürün ihracatı, dış ticaret dengesi ve ekonomik büyüme üzerindeki etkileri. Maliye Dergisi, 165(2), 215-240.

Gökmen, Y. ve Turen, U. (2013). The Determinants of high technology exports volume: A panel data analysis of EU-15 countries. International Journal of Management, Economics and Social Sciences 2(3), 217-232.

Grossman, G. M. ve Helpman, E. (1990). Trade, innovation, and growth. The American Economic Review, 80(2), 86-91.

Güneş, S., ve Tuğba, A. K. I. N. (2019). Yüksek teknolojili ürün ihracatı: Lider ülkeler ve Türkiye analizi. Sosyoekonomi, 27(40), 11-29.

Harris, R. ve Li, Q. C. (2009). Exporting, R\&D, and absorptive capacity in UK establishments. Oxford Economic Papers, 61(1), 74-103.

Huang, C., Zhang, M., Zhao, Y. ve Varum, C. A. (2008). Determinants of exports in China: a microeconometric analysis. The European Journal of Development Research, 20(2), 299-317.

Ismail, N. W. (2013). Innovation and high-tech trade in Asian countries, International Conference On Recent Developments in Asian Trade Policy And Integration Konferansı Bildirileri, Teaching Centre of the University of Nottingham Malaysia Campus 20th and 21st February 2013, Kuala Lumpur, p. 1-19

Jeble, S., Dubey, R., Childe, S. J., Papadopoulos, T., Roubaud, D. ve Prakash, A. (2018). Impact of big data and predictive analytics capability on supply chain sustainability. The International Journal of Logistics Management. 29(2), 513-538. 
Jones, C. I. (1995). Time series tests of endogenous growth models. The Quarterly Journal of Economics, 110(2), 495-525.

Jarreau, J. ve Poncet, S. (2012). Export sophistication and economic growth: evidence from China. Journal of Development Economics, 97 (2), 281-292.

Kamble, S. S., Gunasekaran, A. ve Gawankar, S. A. (2018). Sustainable Industry 4.0 framework: A systematic literature review identifying the current trends and future perspectives. Process Safety and Environmental Protection, 117, 408-425.

Kao, C. (1999). Spurious regression and residual-based tests for cointegration in panel data. Journal of Econometrics, 90(1), 1-44.

Kabaklarli, E., Duran, M. S., ve Üçler, Y. T. (2017, October). The determinants of high-technology exports: A panel data approach for selected OECD countries. In DIEM: Dubrovnik International Economic Meeting,Vol. 3, No. 1, pp. 888-900

Kızılkaya, O., Sofuoğlu, E. ve Ay, A. (2017). Yüksek teknolojili ürün ihracatı üzerinde doğrudan yabancı sermaye yatırımları ve dışa açıklığın etkisi: gelişmekte olan ülkelerde panel veri analizi. Doğuş Üniversitesi Dergisi, 18(1), 63-78.

Kılavuz, E. ve Topçu Altay, B. (2012). Export and economic growth in the case of the manufacturing industry: Panel data analysis of developing countries. International Journal of Economics and Financial Issues. 2(2), 201-215.

Kılıç, C., Bayar, Y., ve Özekicioğlu, H. (2014). Araştirma geliştirme harcamalarinin yüksek teknoloji ürün ihracati üzerindeki etkisi: G-8 ülkeleri için bir panel veri analizi. Erciyes Üniversitesi İktisadi ve İdari Bilimler Fakültesi Dergisi, (44), 115-130.

Kranenburg, V. R. (2008). The Internet of Things: A critique of ambient technology and the all-seeing network of RFID. Institute of Network Cultures.

Koyuncu, G., ve Balan, F. (2020). Endüstri 4.0 bağlamında yüksek teknoloji içeren ürün ihracatı ile işgücü verimliliği ilişkisi: panel nedensellik analizi. Girişimcilik ve Kalkınma Dergisi, 15 (1), 1-10.

Kurt, B. ve Zengin, H. (2016). İthalatın ekonomik büyüme üzerindeki doğrudan ve dolaylı etkileri: Feder-Ram modeli. Uluslararası Ekonomik Araştırmalar Dergisi, 2(4), 67-86.

Lee, J., Kao, H. A. ve Yang, S. (2014). Service innovation and smart analytics for industry 4.0 and big data environment. Procedia Cirp, 16(1), 3-8.

Li, D., Tang, H., Wang, S. ve Liu, C. (2017). A big data enabled load-balancing control for smart manufacturing of Industry 4.0. Cluster Computing, 20(2), 1855-1864.

Liu, X. ve Shu, C. (2003). Determinants of export performance: evidence from Chinese industries. Economics of Planning, 36(1), 45-67.

Liu, J., Chang, H., Forrest, J. Y. L., ve Yang, B. (2020). Influence of artificial intelligence on technological innovation: Evidence from the panel data of china's manufacturing sectors. Technological Forecasting and Social Change, 158, 120142.

Malý, I., Sedláček, D. ve Leitao, P. (2016, July). Augmented reality experiments with industrial robot in industry 4.0 environment. In 2016 IEEE 14th International Conference on Industrial Informatics (INDIN) (pp. 176181). IEEE.

Monostori, L. (2014). Cyber-physical production systems: Roots, expectations and R\&D challenges. Procedia Cirp, 17, 9-13.

Montobbio, F. ve Rampa, F. (2005). The impact of technology and structural change on export performance in nine developing countries. World Development, 33(4), 527-547.

Muscio, A., ve Ciffolilli, A. (2020). What drives the capacity to integrate Industry 4.0 technologies? Evidence from European R\&D projects. Economics of Innovation and New Technology, 29(2), 169-183. 


\section{O. Yavuz 13/1 (2021) 825-843}

Nassimbeni, G. (2001). Technology, innovation capacity, and the export attitude of small manufacturing firms: a logit/tobit model. Research Policy, 30(2), 245-262.

Oesterreich, T. D. ve Teuteberg, F. (2016). Understanding the implications of digitisation and automation in the context of Industry 4.0: A triangulation approach and elements of a research agenda for the construction industry. Computers in Industry, 83, 121-139.

Özer, C. S. (2020). İletişim perspektifinden “Nesnelerin İnterneti”. NOSYON: Uluslararası Toplum ve Kültür Çalışmaları Dergisi, (5), 89-101.

Özer, M. ve Çiftçi, N. (2009). Ar-ge harcamaları ve ihracat ilişkisi: OECD ülkeleri panel veri analizi. Dumlupınar Üniversitesi Sosyal Bilimler Dergisi, 23(3), 39-50.

Özçelik, Ö., Aslan, V. ve Özbek, R. I. (2018). Arge harcamalariyla yüksek teknoloji ihracati arasindaki ilişki: seçili 10 OECD ülkesi için panel veri analizi. Kastamonu Üniversitesi İktisadi ve İdari Bilimler Fakültesi Dergisi, 20(3), 57-66.

Özkan, G., ve Yilmaz, h. (2017). Ar-Ge harcamalarinin yüksek teknoloji ürün ihracati ve kişi başi gelir üzerindeki etkileri: 12 AB ülkesi ve Türkiye için uygulama (1996-2015). Bilgi Ekonomisi ve Yönetimi Dergisi, 12(1), 112.

Pesaran, H. M. (2004). General Diagnostic Tests for Cross-sectional Dependence in Panels. University of Cambridge, Cambridge Working Papers in Economics, 435.

Pesaran, M. H. (2007). A simple panel unit root test in the presence of cross-section dependence. Journal of Applied Econometrics, 22(2), 265-312.

Pohjola, M. (2000). Information Technology and Economic Growth: A cross-country analysis. UNU World Institute for Development Economics Research, Working Papers No. 173, Helsinki, Finlandiya

Rodič, B. (2017). Industry 4.0 and the new simulation modelling paradigm. Organizacija, 50(3), 193-207.

Romer, P. M. (1986). Increasing returns and long-run growth. Journal of Political Economy, 94(5), 1002-1037.

Rüßmann, M., Lorenz, M., Gerbert, P., Waldner, M., Justus, J., Engel, P. ve Harnisch, M. (2015). Industry 4.0: The future of productivity and growth in manufacturing industries. Boston Consulting Group, 9(1), 54-89.

Sahin, B. E. (2019). Impact of high technology export on economic growth: An analysis on Turkey. Journal of Business Economics and Finance, 8(3), 165-172.

Sandu, S. ve Ciocanel, B. (2014). Impact of R\&D and Innovation on High-tech Export. Procedia Economics and Finance, 15, 80-90.

Şahbaz, A., Yanar, R., ve Adıgüzel, U. (2014). Ar-Ge harcamaları ve ileri teknoloji mal ihracatı ilişkisi: panel nedensellik analizi. Çukurova Üniversitesi Sosyal Bilimler Enstitüsü Dergisi, 23(1), 47-60.

Şeker, A. (2019). Teknolojik gelişme ve yüksek teknoloji ihracatının ekonomik karmaşıklık endeksi üzerindeki etkisi: Türkiye örneği. Yönetim ve Ekonomi: Celal Bayar Üniversitesi İktisadi ve İdari Bilimler Fakültesi Dergisi, 26(2), 377-395.

Singh, L. (2006). İnnovations, high-tech trade and industrial development: theory, evidence and policy, WIDER Working Paper Series 027, World Institute for Development Economic Research (UNU-WIDER).

Srholec, M. (2007). High-tech exports from developing countries: A symptom of technology spurts or statistical illusion?. Review of World Economics, 143(2), 227-255.

Švarcová, J., Urbánek, T., Povolná, L., ve Sobotková, E. (2019). Implementation of R\&D results and industry 4.0 influenced by selected macroeconomic indicators. Applied Sciences, 9(9), 1846.

Stock, T. ve Seliger, G. (2016). Opportunities of sustainable manufacturing in industry 4.0. Procedia Cirp, 40, 536541.

Şeker, A. (2018). Teknoloji transferinin teknolojik gelişim, üretim ve yüksek teknoloji ürünlerinin ihracati üzerindeki etkisi: Türkiye örneği. Business \& Management Studies: An International Journal, 6(3), 583-603.

Thames, L. ve Schaefer, D. (2017). Cybersecurity for Industry 4.0. New York: Springer. 


\section{O. Yavuz 13/1 (2021) 825-843}

Tebaldi, E. (2011). The determinants of high-technology exports: A panel data analysis. Atlantic Economic Journal, 39(4), 343-353.

Telatar, O. M., Değer, M. K. ve Doğanay, M.A. (2016). Teknoloji yoğunluklu ürün ihracatının ekonomik büyümeye etkisi: Türkiye örneği (1996:Q1-2015:Q3), Atatürk Üniversitesi İktisadi ve İdari Bilimler Dergisi, 30(4), 921934.

Topallı, N. (2015). Doğrudan yabancı yatırımlar, ekonomik büyüme ve yüksek teknoloji ihracatı arasında bir nedensellik ilişkisi. International Journal of Social Sciences and Education Research, 1(1), 277-285.

Türedi, S. (2013). Bilgi ve iletişim teknolojilerinin ekonomik büyümeye etkisi: Gelişmiş ve gelişmekte olan ülkeler için panel veri analizi, Gümüşhane Üniversitesi Sosyal Bilimler Elektronik Dergisi, 4(7), 298-322.

Ustundag, A. ve Cevikcan, E. (2017). Industry 4.0: Managing the Digital Transformation. Springer, İsviçre.

Wan, J., Yi, M., Li, D. I., Zhang, C., Wang, S. ve Zhou, K. (2016). Mobile services for customization manufacturing systems: An example of industry 4.0. IEEE Access, 4, 8977-8986.

Wignaraja, G. (2012). Innovation, learning, and exporting in China: Does R\&D or a technology index matter?. Journal of Asian Economics, 23(3), 224-233.

$\mathrm{Xu}, \mathrm{D}$. L., He, W. ve Li, S. (2014). Internet of things in industries: A survey. IEEE Transactions on Industrial Informatics, 10(4), 2233-2243.

Yaman, H., ve Sungur, O. (2020). İleri teknoloji ihracati ve büyüme ilişkisi: OECD ülkelerine yönelik ekonometrik bir analiz. Bolu Abant İzzet Baysal Üniversitesi Sosyal Bilimler Enstitüsü Dergisi, 20(1), 63-80.

Yavuz, G., ve Uysal, Ö. (2020). Yüksek teknolojili ürün ihracatini etkileyen faktörlerin analizi: OECD Örneği. Uluslararası Ekonomi İşletme ve Politika Dergisi, 4(1), 205-220.

Yapraklı, S. ve Sağlam, T. (2010). Türkiye'de bilgi iletişim teknolojileri ve ekonomik büyüme: Ekonometrik bir analiz (1980-2008), Ege Akademik Bakış, 10(2), 575-596.

Yıldırım, E. ve Kesikoğlu, F. (2012). Ar-Ge harcamalari ile ihracat arasindaki nedensellik ilişkileri: Türkiye örneğinde panel nedensellik testi kanitlari. Marmara Üniversitesi İktisadi ve İdari Bilimler Dergisi, 32(1), 165-180.

Yıldız, Ü. (2017). BRICS ülkeleri ve Türkiye'de yüksek teknoloji ihracatı ve ekonomik büyüme ilişkisinin panel veri analizi, Dumlupınar Üniversitesi Sosyal Bilimler Üniversitesi Dergisi, (53), 26-34.

Zhang, K. H. (2007). Determinants of complex exports: Evidence from cross-country data for 1985-1998. Economia Internazionale/International Economics, 60(1), 111-122. 